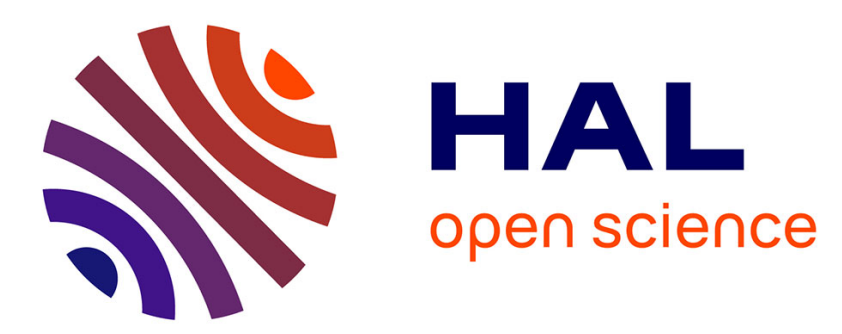

\title{
The Power of International Reserves: the impossible trinity becomes possible
}

Layal Mansour

\section{To cite this version:}

Layal Mansour. The Power of International Reserves: the impossible trinity becomes possible. 2014. halshs-01054614

\section{HAL Id: halshs-01054614 \\ https://shs.hal.science/halshs-01054614}

Preprint submitted on 7 Aug 2014

HAL is a multi-disciplinary open access archive for the deposit and dissemination of scientific research documents, whether they are published or not. The documents may come from teaching and research institutions in France or abroad, or from public or private research centers.
L'archive ouverte pluridisciplinaire HAL, est destinée au dépôt et à la diffusion de documents scientifiques de niveau recherche, publiés ou non, émanant des établissements d'enseignement et de recherche français ou étrangers, des laboratoires publics ou privés. 
The Power of International Reserves: the impossible trinity becomes possible

Layal Mansour 


\section{GATE Groupe d'Analyse et de Théorie Économique Lyon-St Étienne}

93, chemin des Mouilles 69130 Ecully - France

Tel. +33 (0)4 72866060

Fax $+33(0) 472866090$

6, rue Basse des Rives 42023 Saint-Etienne cedex 02 - France

Tel. +33(0)4 77421960

Fax. +33 (0)4 77421950

Messagerie électronique / Email : gate@gate.cnrs.fr

Téléchargement / Download : http://www.gate.cnrs.fr - Publications / Working Papers 


\title{
The Power of International Reserves: the impossible trinity becomes possible.
}

\author{
Layal MANSOUR Ph.D Student \\ Université de Lyon, Lyon, F-69007, France ; CNRS, GATE Lyon Saint-Etienne, Ecully, \\ F-69130, France ; Université Lyon 2, Lyon, F-69007, France.
}

\begin{abstract}
This aim of the present paper is to measure first, the degree of trilemma indexes: exchange rate stability, monetary independence capital account openness while taking into account the increase of hording IR ratio over GDP, over External Debt and over Short Term External Debt. The evolution of the trilemma indexes shows that countries applying de facto flexible Exchange Rate Regime (ERR) take advantage of the IR and become able to adopt a managed ERR that consist of achieving the three trilemma indexes simultaneously without renouncing to anyone of them. We found that different IR ratio could have different interpretations and different directions of monetary policies, where external debt should be taken into consideration in such study while using the IR. As for country that is applying a de facto fixed exchange rate regime, the IR (different ratio) do not play any role in changing the patter of the Mundell trilemma and do not intervene in monetary authority policies. This paper treats as well the normative aspects of the trilemma, relating the policy choices to macroeconomic outcomes such as the volatility of output growth. We found different results from country to another, while taking different ratios of measuring IR, concluding that the impact of IR on the output volatility could change due to the level of external debt and adopted exchange rate regime.
\end{abstract}

Keywords: Monetary policy, International Reserve, External Debts, Impossible Trinity, Managed Exchange Rate, Quadrilemma, Output Volatilily.

Mots clés : Politique Monétaire, Réserves Internationales, Dettes externes, l'Impossible Trinité, Quadrilemme, Taux de Change Administré, Volatilité de la Croissance de Production.

JEL: E52, E58, F31, F34 


\section{Introduction}

"Exchange rate stability in emerging countries can be considered as an international public good because it facilitates the recycling of the savings of the rich and aging population of industrialized countries to the economies of the South in search of capital ${ }^{1}$ ".

The problem of choosing the adequate exchange rate regime for a country is not recent, but date for about two centuries. It is after the collapse of the Bretton Wood system that this issue becomes familiar, popular and more developed with high interest by most of economists in the world. "Flexible versus fixed exchange rate dichotomy" were the topic of studies of many economists since 1950s, such Friedman (1953) and Johnson (1969), Atish, Gulde, Ostry, Wolf (1997), Devereux, Engel (1998) where they were analyzing the advantages of flexible exchange rate and fixed exchange rate. They share the conclusion that fixed exchange rate regime is associated with lower and less inflation rate and lower rate of monetary growth, while flexible exchange rate regime is associated with volatility of output and employment. Mundell (1960), theorized in his analysis by studying characteristic of capital mobility with exchange rate regime. He concluded that when a country adopts capital liberalization, the best combination with it would be applying a fixed exchange rate regime in order to avoid the influence of the interest rate on the balance of payment. To avoid excessive price volatility and to attract foreign capital, these countries seek to anchor their currencies, formally or informally, to the dollar or to a basket of foreign currencies. This policy may well contribute to economic growth for some time. However, the fixed exchange rate is sustainable only if inflation in the country in which the nominal anchor (peg) converges to that prevailing in the country where it anchors its currency. Most often, this condition is not sufficiently filled, and the combination of excessive real appreciation and external deficits cause a crisis and a sharp adjustment in the exchange rate. If there is no capital mobility, it would be preferable to adopt a floating exchange rate regime, in addition that floating regimes appear to offer at least a degree of temporary monetary independence (Frankel, Schmukler, Servén 2004). Flexible or fixed, monetary authority has to trade-off between two extreme exchange rate regimes (corner solutions) 1-totally flexible or 2-totally pegged are related to two main objectives: the first objective is to promote price stability (by minimizing variation of the output and prices), and the second objective is related to afford welfare (by maximizing the

\footnotetext{
${ }^{1}$ Jacquet P (1999) in Bergsten F, Davanne O, Jacquet P ; Pour une gestion conjointe de la flexibilité des changes ; in F. Bergsten et alli (eds), Architecture financière internationale, Rapport du Conseil d'Analyse Economique, $\mathrm{n}^{\circ} 18$, La Documentation Française, Paris, p.9-54.
} 
utility function). Whether Fridman (1953), Mundell (1960, 1961, 1963), Aizenman and Frankel (1985), Aizenman and Hausmann (2001), defend the first objective, other economists such Lapan and Enders (1980), Helpman (1981), Eaton (1985), Chinn and Miller (1998), Neumeyer (1998) and Obstfeld and Rogoff (1998) defend the second objective. All together agreed that there is no optimal exchange rate regime to be adopted by a country, especially for a country vulnerable to chocks. Thus Ripoll (2001) listed several factors that should be taken into consideration for each country before adopting any kind of exchange rate regime: the importance and the degree of financial openness, the capital mobility of the economy, the inflation level, internal and external chocks, capital mobility, prices and wages flexibility degree, monetary authority flexibility degree and price system fixation.

Since the development of the Mundell Fleming "trilemma" in 60s, or the "impossible trinity" that showed that it is impossible for a country to associate simultaneously the financial openness with the stability of exchange rate regime and the monetary independence (figure 1a) the theory has remained strong. On one side sustainability of the impossible trinity was argued by Eichengreen (1996), Calvo and Reinhart (2001), Bordo and Flandreau (2003), Obstfeld and Taylor (2004), Allégret (2007), Aizenman Chinn et Ito in (2008) and Aizenman and Glick (2008) and many other economists. On the other side the robustness of the impossible trinity was clear with the real experiences of the emerging countries in the 90s and 2000s, when they suffered from severe financial crises while they wanted to challenge the impossible trinity. Since the current turbulence in the global financial market can be beaten with the stability of the current configuration of the trilemma, we are witnessing breach of the trilemma configuration.

With the world globalization, avoiding the financial openness becomes more and more difficult, and even impossible for some emerging countries that benefits from a very high economic growth and financial growth. Therefore, Emerging Countries (EC), with a very big prevention and attention of suffering from financial crisis like they did previously in 90s and 2000s (Figure 1b), tried to follow the globalization trend and open their financial market without renouncing neither to monetary independence nor the exchange rate stability especially that this latter is primary. As explained by Bergsten F, Davanne O, Jacquet P; (1999), instability of exchange rate can occur to the availability of the external finance for both reasons: the possible loss of credibility of economic policy and the need to serve for foreign investors or local investors who fund outside a potentially high risk premium to compensate for currency risk increased. In total, the cost of capital and the level of investment 
could be severely affected in those emerging countries which do not try to limit the volatility of their exchange rate.

Previous experiences with severe financial crisis of Latin America and Asia proved that: crisis of Mexico in 1994, Thailand, Indonesia and Korea in 1998, Russia, Brazil and Turkey in 2000 are all related to the impossibility to achieve the 3 goals simultaneously (figure 1b).

Figure 1 a -The Traditional Mundell Trilemma, known as the impossible Trinity

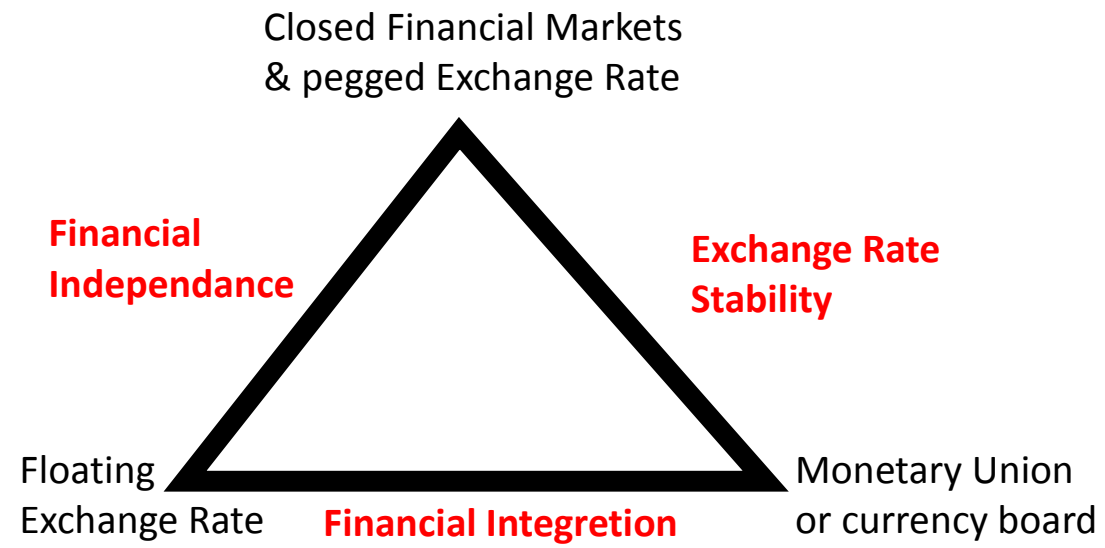

Figure 1 b -The Challenge Mundell Trilemma, and Crisis

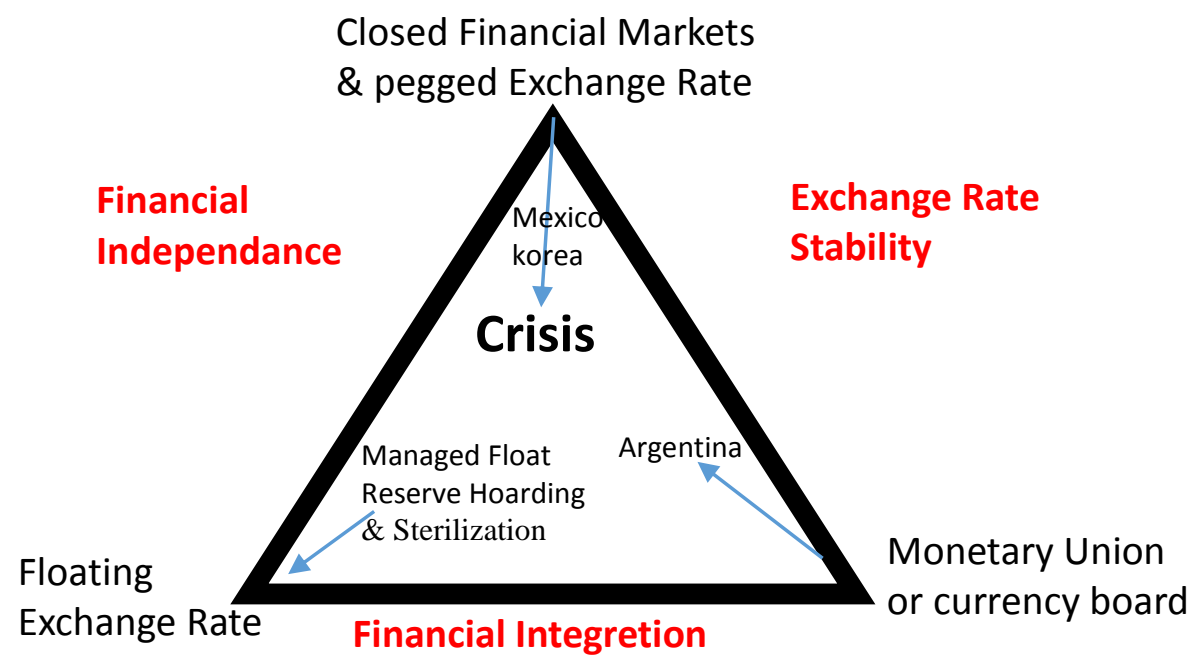

Although the "impossible trinity" has become self-evident for most academic economists and it shared by politicians and monetary authorities, in practice, most countries (emerging countries) may face a challenge to achieve all of the 3 peaks of the Mundell triangle or at least countries are shifting their configuration to adapt to new challenges and changing economic and global structures as shown in the (Figure 2). 
Figure 2: The evolution of Trilemma indices over time ${ }^{2}$

a- The evolution of Trilemma indices in Emerging Market countries

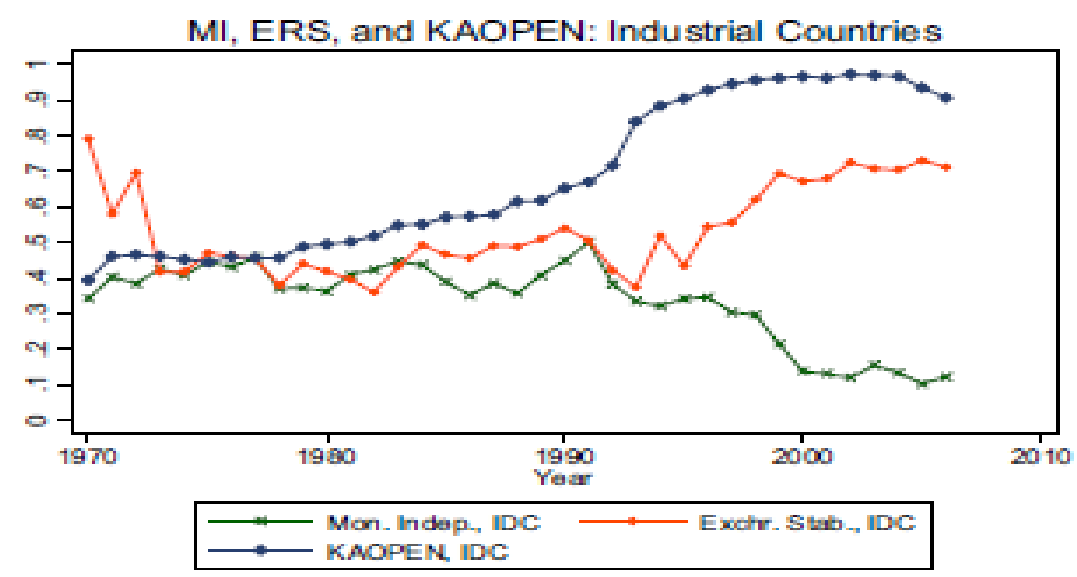

b- The evolution of Trilemma indices in developing countries (emerging /not emerging)
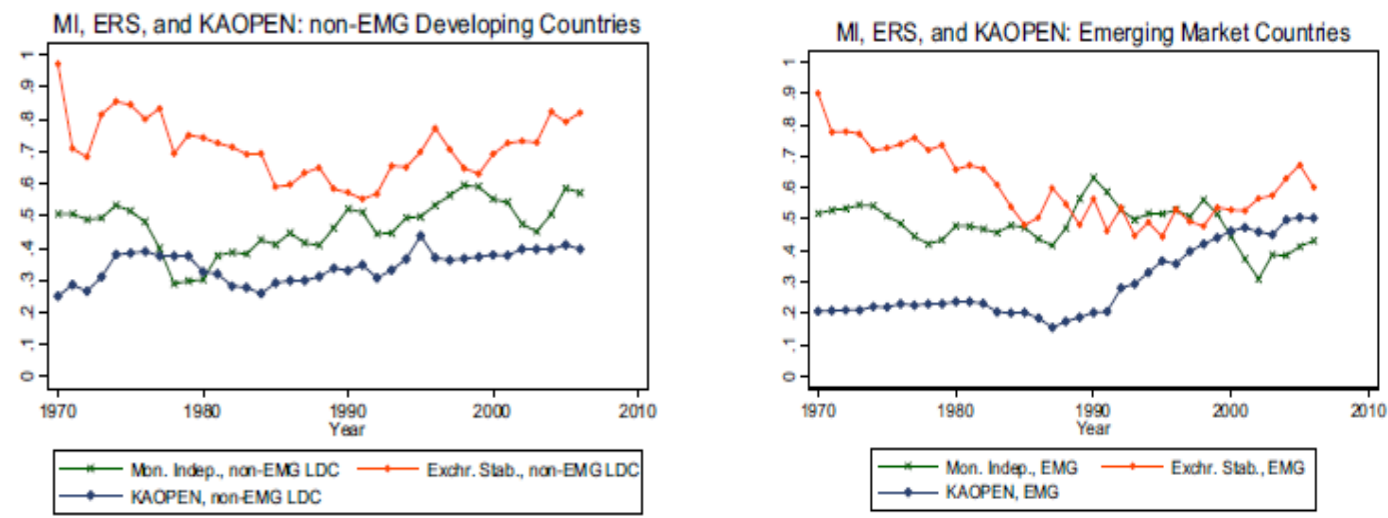

How can EC achieve these goals that are known impossible? The "degree of flexibility" of the exchange rate was mainly created to complete/challenge the Mundell triangle, know as well as Mundell Trilemma or Impossible trinity. With numerous and different crisis affecting the economy, the issue of possible existence of new configurations of international financial system (Allegret 2000,2005) and a "degree of flexibility" (Frankel (1999, 2004), Aizenman et al (2008), Popper, Mandnilaras, Obsfeld, Shambough (2011), were discussed nowadays.

According to Devereux et al (2003) and Obsfelt (2006), flexible exchange rate regime is always desired by countries, except for dollarized country, where flexible exchange rate (even if it is desired) is difficult to be adoptable without leading to a financial crisis (Mishkin and

${ }^{2}$ Aizenman, Chinn and Ito (2010) 
Savastano 2001). Therefore, a degree of flexibility would be preferable, and should be determined according to the developed level of each country, Rogoff (2004). In practice, most of emerging countries, Latin America Countries and Asian countries are adopting the managed exchange rate regime: a floating exchange rate regime with frequent officials interventions and theses interventions are due to hoarding International Reserves.

Here comes one of the important roles of hoarding IR, in addition of the main role of International Reserves that provide an effective cushion against external shocks (Annex 1figure 1), it also may let a country to open its financial market with some degree of exchange rate stability and monetary independence. The IR will let monetary authority to be able to intervene implicitly in the financial market, by manipulating the IR from time to time in order to control the financial market. That's why it is called managed floating exchange rate regime. (Not totally pegged, not totally free capital mobility, not totally monetary independence). Thus, the degree of adopting every policy "becomes a variable", where a country can increase its first monetary objective by decreasing other monetary objective or decreasing the weighted average of the other policies.

In many studies of Aizenman (2008, 2011, 2012), Obsfeld (2004) and Ortiz and Rodriguez (2002), they showed the relation between hoarding IR and the choice of the trilemma objectives. But what is "innovative" and advanced to mention, is that the IR "may" be added as a fourth objective, because experiences showed that "no 3 without 4". This was one of the main topic for many economists such Aizenman, Popper, Mandnilaras, Obsfeld, Shambough and other; thus, "the impossible becomes possible and the triangle of three policies becomes a diamond chart with four policies.

If above explanations seem to be simple, the practice shows that it is not, and even complicated.

Before trying to represent the $N E W$ configuration of the Mundell triangle, we must address several problems such as the adequate level of hoarding IR and the cost of hoarding IR:

\section{*Adequacy level of International Reserves and the Cost of Hoarding IR.}

Ideally, decisions on reserves should be governed by an analysis weighting the benefits of reserves against cost, but in practice, there is a huge uncertainty about both the utility and cost function that would inform such analysis. 


\section{*The adequate level of hoarding IR}

The optimal level of IR were discussed many years ago, with Frenkel and Jovanovic (1981) and Ben Brassat and Gottlieb (1992) since hoarding IR practice started; but the rapid increase of the IR that have reached more than six fold in the past decade raises the question whether this accumulation is excessive or not, thus witness further mathematics and macroeconometrics studies on this field. In addition, taking into account the cost of hoarding IR open the discussion on what is called the adequate level of International Reserves. According to the IMF balance of payment manual, the adequacy of reserves is assessed by their capacity to prevent or mitigate external shocks (figure $2 \mathrm{c}$ ).

\section{Figure 2 c- Change in Reserves during the Crisis}

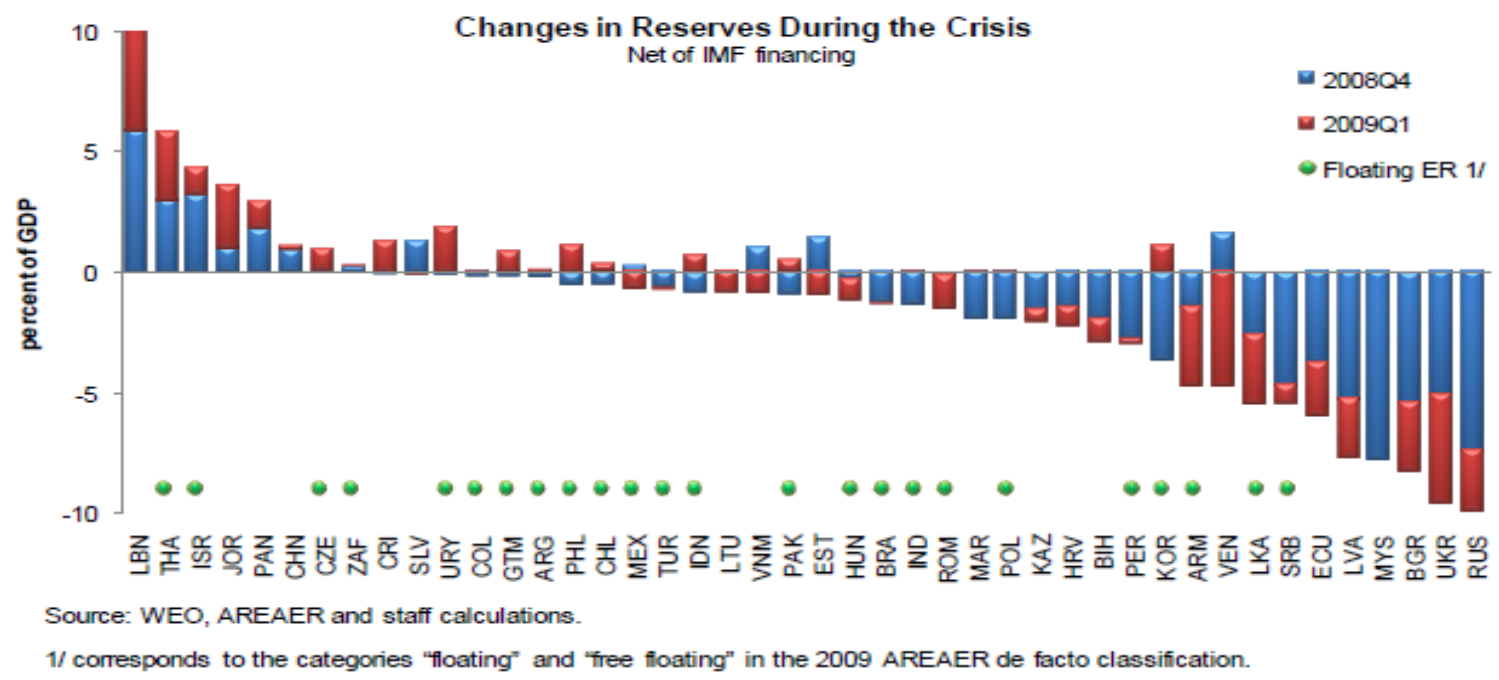

General measurement of IR are calculated by dividing the IR on GDP. This latter is considered such having little theoretical or empirical backing; probably best used simply as a scaling factor for cross-country analysis. IMF study entitled Assessing Reserve Adequacy were focused on the IR level and the adequate IR level, by proposing ratio and examining them empirically. Unlike Aizenman et $a l$ who used IR on GDP in their several/all studies, IMF discussion concerning the adequate level of IR suggest to calculate IR on Total External Debt and/or Short Term External Debt (STED) or Import or even on M2; especially after the Korean crisis 1997. In 1999, Pablo Guidotti and Alan Greenspan propose the GuidottiGrenspan Rule (GGR). This period was marked by "sudden stop" cases, where finance by external currency was not so evident (Calvo and Reinhart 2000). 
He started his idea by saying that a country could be able to pay interest on its external debt, but will not be able to repay a principal balance that it had expected to roll on. That is why the Guidotti-Grenspan Rule is based particularly on the level of IR that countries should possess in order to cover full amortization for up to one year without access to foreign credit. This latter is not far from the suggestion of Keynes when he talked about the accepted principles governing the optimal level of free gold reserves, in its second volume of his treatise on money $(1930)^{3}$. The GGR was hold up in practice by many econometric and theoretical studies such by the regression done by Aizenman and Marion (2004) about the IR and it growth trend in the East Asian countries, since the Asian crisis. In fact regression test were linked to the theoretical model of the auto-insurance against sudden strop. Econometric results talked about mechanism through which no crisis have influenced subsequent reserve holding.

Jeanne and Ranciere (2009), and Jeanne (2007) have estimated the level of optimal IR in a model that serves of role of letting national consumption smoothing in the face of random sudden stops. Durdu, Mendoza and Terrones (2009) focus on potential sudden strops as a motivation of reserve demand. Consistent with Summer's observations (2006), countries that hoard excessive IR relatively to the Guidotti-Grennspan Benshmark, in some cases, they multiply their short term external debt. In fact, External debt arguments for reserve holdings emphasize that a negative (capital flow) balance of payment shock can emanate from the financial account when the export of home assets to foreigners suddenly stops. (Similar shocks can occur when foreign assets by domestic residents suddenly starts).

In an IMF survey in 2011 entitled "Assessing the Need for Foreign Currency Reserves', the "rules of thumb" that have been used to guide reserve adequacy and suggesting that countries should hold reserves covering 100 percent of short-term debt or the equivalent of 3 months' worth of imports becomes nowadays not applicable. In fact, despite their appeal in terms of simplicity and transparency, in practice and in 2009, median reserve coverage ratios considerably exceeded these norms in emerging markets, standing at about six months of imports, and 200 percent of short-term debt. Other paper of IMF 2011, entitled optimal precautionary reserves for low income countries: a cost-benefit analysis who focus their analysis on cost-benefit approach in low income study didn't find same conclusion. In fact, they found that rule of thumb gives imprecise benchmarks, IR could find solution to vulnerability in short term only. If solution at long run is searched, policy should rather focus

\footnotetext{
${ }^{3}$ in Obsfeld \& al 2008
} 
on strengthening policy frameworks, increasing exchange rate flexibility and diversifying economies.

Some economists such Arize and Malindretos 2012, (and Dutta (1964), Kantie (1972) and Pani (1977) $)^{4}$ look at the consequence of increasing IR beyond the opportunity of the IR such as maintaining the exchange rate stability. Consequence of hoarding International Reserves was examined by empirical study in Asian countries. They find that the increase of IR may have a positive effect on the demand for import. The source of the IR has been export earning remittances of Asians residing abroad, and in few cases, foreign assistance. As a consequence, import of Asian countries such India, Korea, Singapore and Thailand from 1973 to 2010 , import grew at a higher rate to achieving $20 \%$ yearly for some countries.

In fact, the higher is the level of foreign exchange reserves, the less is the policy restrictive. With regard to international trade, IR (foreign currency) is often an indispensable requirement to finance imports of goods and services. That is, IR plays a paradox role, negative role by encouraging import. Given the importance of Import and the positive relation with hoarding IR, Import level couldn't be negligible anymore, therefore, it is important to note that several studies included the IMF studies consider that the adequate level of hoarding IR is measure by dividing the IR on the Import level: the IR to Import ratio. This ratio remains relevant as it can measure in a simple way the level of reserves by the size and openness of the economy. The main interpretation of the reserve on month import ratio is that it shows the number of months a country can continue to support its current level of imports if all other inflows or outflows stop. The measurement of this ratio focuses on the current account, and could be used in general for country that need reserves and limited access and vulnerabilities to capital markets. It should be notes that import data generally suffer from relatively few measurement problems which makes the indicator generally less suitable for analyzing vulnerability in industrialized countries. For countries with limited access to capital markets, the variability of the current account is also important, as reserves are then needed to buffer the impact of shocks to the current account.

According to Obsfeld, Shambaugh and Taylor (2008), Reserve adequacy should be calculated on M2 (broad money) and that M2 has greater explanatory power than other traditional factors such GDP. As for the IMF, IR/GDP is less based as an indicator, but in a context where capital account crisis where we witness outflows of deposit of domestic

\footnotetext{
${ }^{4}$ In Arize and Malindretos 2012
} 
resident, IR/M2 may be useful to detect risk of capital flight and can be considered as a counter indicator of some crisis.

Recently, Obsfeld et al (2009) mentioned that despite the focus on the "GuidottiGreenspan" rule and sudden stops in the literature, short term external debt is not a significant predictor of reserve holdings, though another variable often considered in more traditional models, the Trade/GDP ratio is. Briefly, either the first or the second ratio, the inclusion of Trade Balance and external debt should be considered.

Finally, Calvo, Izquierdo and Loo-Kung (2012) explored the optimality of IR and found that generally countries are not exceeding their accumulation of IR; policymakers are taking into account their proper economic context such currency denomination mismatch and current account deficit.

\section{*The Cost of International Reserves}

It is evident that Reserve have been important in both preventing crises and mitigating their impact (figure 3) but they are costly (at both the national and global level) and subject to weakening profits. Therefore, once the reserves increase beyond adequate levels, it becomes very important to focus relatively more on the other elements of sovereign risk management frameworks, such contingent financing mechanisms and country insurance, and general macroeconomic and prudential policies. That is why decisions about hoarding IR should be governed by a weighted the benefit against the cost of hoarding IR.

In fact as cited in the European Central Bank ${ }^{5}$, a continued reserve accumulation may lead over time to some risks and cost such as inflationary pressures, over investment and asset bubble. As well as for Ortiz and Rodriguez (2002), as continued "over" accumulation of IR may lead to strange demands on a Central Bank's foreign exchange reserves especially in a context of risky financially open economy, where potential currency mismatches and a combination of internal drains (runs from bank deposits to currency) and external drains (flight to foreign currency or banks) exist. In the empirically prevalent scenarios of "twin" internal and external drains (Kaminsky and Reinhart 1999), reserve backing falls when the central bank attempts to ease domestic illiquidity by acting as a lender of last resort (LLR). Yeyati (2008) discussed about the cost of hoarding International Reserves as well as Bird and Rajan (2003) and Rodrik (2006), they suggest that instead of protecting themselves by hoarding IR, EMC would rather attack the sources of the vulnerability directly. Popper et al

\footnotetext{
${ }^{5}$ European Central Bank, 2006, The accumulation of foreign reserves; occasional paper series, $\mathrm{N}^{\circ} 43$.
} 
(2011) conclude that the policy stability procured by hoarding IR is limited to -only- low income countries, but not in middle income or high income level. According to Cook and Yetman (2012) who confirmed the importance of hoarding IR in avoiding or mitigating financial crisis (during stress/crisis times and not in normal times), addresses how negative on the long run prospect for the economy could be holding a large stock of foreign reserves even if the inflationary effects of the reserves are fully sterilized. It could distorted central balance sheet, and private sector's balance sheet. It also may have negative effect on bank lending and investment.

In this article, we represent graphically changes in degree for achieving simultaneously three objectives of the Mundell triangle as well as the diamond chart while including the IR and we represent the extent in divergence in all three trilemma policies. Unlike Aizenman \& al (2008) who used IR/GDP in their analysis and calculations, we introduce ration of IR/ED and IR/STED in order to compare results and to conclude whether ED or STED change obviously results. We conclude the article by examining the impact of the trilemma policy and its interaction with the level of Reserve (IR/GDP, IR/STED and IR.ED) on the Output volatility.

Countries chosen: Lebanon, Turkey, Argentina, Brazil and Mexico, are not necessarily identical in terms of growth, development, inflations, or other, but similar in terms of highly hoarding International Reserves, suffering from a high level of External debt and witnessed a turning point in their monetary economy. Because Turkey, Argentina, Brazil and Mexico are emerging countries and experienced similar business cycles and specially have suffered from debt crisis and economic events such in 1982, 1997 and 2001, in addition of hoarding IR and suffering from external debt, these countries will be considered in our study as a sub-sample group of countries. Lebanon will be studied alone, due to its particularity in terms of crisis, and one unique major economic event that is described below.

\section{Empirical method}

Obsfeld Schaubaugh, Taylor (2004) studied the robustness of the Mundell trilemma through the interest rate, and the latter confirmed that the Mundell trilemma is the guide of politic structures, and Glick (2010) studied the relation between capital control and future crisis. Rare are economists who changed the configuration of the Mundell Felming model, such Ortiz and Roeriguez (2002) who extended the model by introducing the fiscal deficit and IR as determinants of the level of country risk, and Aizenman (2008-2010) by introducing the IR as a $4^{\text {th }}$ objective leading the monetary authority to achieve at the same time the 3 
"impossible" goals. Our study refers to Aizenman study because it introduces in a very explicit way the IR and its relation with the three goals of Mundell fleming model simultaneously during years and not only the relation between the IR and one goal of the triangle. In addition, most of all recent studies on this topic are based on Aizenman (20082010). Thus, we construct for each country a vector of the trilemma and the IR configuration in order to measure the Monetary Independence (MI), the Stability of the Exchange Rate regime (ERS), the financial openness (KAOP) and the IR. As mentioned above, increasing one variable of the Trilemma policy will be followed with a decrease of the weighted average of the two others: thus, the "trade off" in the objective's choice. This tradeoff is considered as linear, in other term, the weighted average sum of the three variables is equal to a constant.

The monetary independence (MI) is based on the correlation of a country's interest rates with the base country's interest rate. To measure the index of the exchange rate stability (ERS), we consider the invert of exchange rate volatility, i.e., standard deviation of the monthly rate depreciation, using the exchange rate between the home and the base economies. As for measuring the degree of the financial integration, we will take the Capital Control index (KAOPEN) of the study of Chinn-Ito (2006, 2008). The constructive way of these indexes has been applied and extended to several studies, including Hutchison, Sengupta and Singh (2010), Cortuk and Singh (2011), and Popper, Mandalaras, and Bird (2011). Once indexes are constructed, we do an index of divergence of the three trilemma policy choices and evaluate its patterns in recent decades. All measures are normalized between 0 and 1. We use the Trilemma indexes by measuring the: MI (Monetary Independence), the ERS (Exchange Rate Stability) and the KAOPEN (financial openness, financial integration)

\subsection{The MI (Monetary Independence)}

will be calculated in the following way:

$\mathrm{MI}=1-\frac{\operatorname{corr}(i i, i j)-(-1)}{1-(-1)}$

$\mathrm{i}=$ domestic country and $\mathrm{j}=$ based country ${ }^{6}$.

Value $[0,1] \quad$ if value $\rightarrow 1$, there is important monetary independence.

\footnotetext{
${ }^{6}$ Based countries are refered to study of Shambough 2004.
} 


\subsection{The ERS (Exchange Rate Stability)}

Should the ERS indicator variable be classified by its de jure or de facto status (Ghosh é al, 1997)? A country's actual exchange rate regime choice usually departs from its selfreported status, as published by the International Monetary Fund (IMF) and code de la monnaie. The preferred approach is therefore to examine what countries do, not what they say (Obstfeld and Rogoff 1995; Calvo and Reinhart 2001, 2002; Levy-Yeyati and Sturzenegger 2002; Reinhart and Rogoff 2004).

The ERS is calculated as the annual standard deviation of the monthly exchange rate between the domestic country and base country. They are calculated and are included in the following formula in order to normalize the index between 0 and 1 .

$\mathrm{ERS}=\frac{0.01}{0.01+\operatorname{stdev}(\Delta(\log (\text { exch_rate })))}$

This formula can suffer from bias in the index and can give us a devaluated or revaluated the flexibility of the exchange rate. Therefore, according to the literature, we apply a threshold to the exchange rate movement. Thus, if the rate of monthly change stayed within $+/-0.33 \%$ bands, we consider the exchange rate is "fixed" and assign the value of one for the ERS index.

In fact then $+/-0.33 \%$ bands is based on the $+/-2 \%$ based on the annual rate, that is often used in the literature. As well if the exchange rate had percentage change of zero in eleven out of twelve months, it is considered as peg, as so we avoid breaks in the peg status due to one-time realignments.

Higher values of the ERS index indicate more stable movement of the exchange rate against the currency of the base country.

\subsection{KAOP: Capital openness, Financial Openness/Integration}

It is very difficult to measure the extent of capital account control. Several economists such Edison et Warnock (2001), Edwards(2001), Edison et al (2002), Kose et al (2006) et Chinn et Ito (2008) were interested in measuring the financial openness in different ways by measuring the capital restriction. Following the model of Chinn and Ito $(2006,2008)$ by calculating the KAOP based on information's about restriction of financial integration. AREAER « Annual Report of Exchange Arrangements and Exchange Restrictions of the IMF. The KAOP is the first standardized principal component of the variable that indicate the presence of multiple exchange rates, restrictions on current account transaction, on capital account transactions and the requirement of the surrender of export proceeds (chin and Ito 
2008). It is important to distinguish between de jure and de facto index of capital openness.

As long as the de jure index indicates the intention of the monetary authority, we chose de jure whether than de facto, because this latter can be more susceptible to other macroeconomic effects than solely policy decisions with respect to capital controls. The index is normalized between 0 and 1 . The closer to 1 is the value; the more open to crossborder capital transactions is the country.

Starting with Chinn and Ito (Journal of development Economics, 2006), they introduced an index that measures country's degree of capital account openness: the Chinn-Ito index (KAOP). This latter is based on the binary dummy variable that codifies the tabulation of restrictions on cross-border financial transactions reported in the IMF's Annual Reports on Exchange Arrangements and Exchange Restrictions (AREAER).

Data are given for 182 countries from 1970 to 2011 and are available online ${ }^{7}$. Trilemma Indices are represented in Annexes, figure $2 \& 3$.

\subsection{Trilemma Indexes and Linear Relationships.}

Previous analyses about macroeconomic policy could be useful to see the evolution of international macroeconomic policy orientation, but could not show whether these three goals are compact with the impossible trinity, but it is essential to prove that countries have faced a trade-off based on trilemma. Thus, as cited above, if the three trilemma variable could not be achievable simultaneously, that means that increasing in one trilemma variable may reduce the second variable trilemma or the third or the combination of the two others. Therefore, to test the validity of the simplest possible trilemma specification, we conduct the linear tradeoff analysis. This linear tradeoff analysis measures if the weighted sum of the three trilemma policy variables is equal to a constant (two) which explains for example that a higher financial integration will be followed by a lower exchange rate stability and a lower monetary independence or a combination of these two policy adjustments.

Consider the following linear regression:

$\mathrm{CST}=\mathrm{a}_{\mathrm{j}} \mathrm{MI}_{\mathrm{i}, \mathrm{t}}+\mathrm{b}_{\mathrm{j}} \mathrm{ERS}_{\mathrm{i}, \mathrm{t}}+\mathrm{c}_{\mathrm{j}} \mathrm{KAOPEN}_{\mathrm{i}, \mathrm{t}}+\varepsilon_{\mathrm{t}}$

Where $j$ represents country (Lebanon) or subsample groups of countries (Turkey, Argentina, Brazil, Mexico). In our example we use a constant equal to two, omitted on the right hand side of the estimation equation. Result and Interpretations will be discussed below.

\footnotetext{
${ }^{7}$ http://web.pdx.edu/ ito/trilemma_indexes.htm
} 


\subsection{From the Trilemma to the Quadrilemma}

While describing the role or the advantage of the IR, we assert on a point that IR allows policymaker to be more flexible in dealing with the short-run tradeoffs between monetary Independence and exchange rate stability, where financial integration is a given. We examine the regression including IR ratio on GDP, STED and ED in order to conclude the role of IR in achieving certain policy goals. These four dimensions constitute the four policy goals, represented in the diamond chart. In each diamond chart for each country or group of country, the origin is normalized so as to represent zero monetary independence, pure float, zero IR and financial autarky. We repeat the same equation of the linearity between the three indexes but this time with including the international Reserves over GDP, over External Debt and over STED. Therefore the linear regression that shows whether countries chosen were really doing a tradeoff between the three macroeconomics policy goals is: $2=a_{j} M_{i, t}+b_{j} E S_{i, t}+c_{j} K A O P E N_{i, t}+d_{j} I R+\varepsilon_{t}(j=$ country or group of countries). Where IR is either IR/GDP or IR/ED or IR/STED

\subsection{The impact of the External Debt and the Short Term External Debt on final policy goals}

We examine the impact of the trilemma policy and its interaction with the level of reserves on one of the main policy goals: the Output volatility

Consider the following regression:

$y_{i t}=\alpha_{0}+\alpha_{1} \operatorname{TRIi}_{t}+\alpha 2 \operatorname{IR}_{\mathrm{it}}+\alpha_{3}\left(\mathrm{TRIi}_{\mathrm{t}} * \mathrm{IRi}_{\mathrm{t}}\right)+\mathrm{X}_{\mathrm{it}} \mathrm{B}+\mathrm{Z}_{\mathrm{t}} \Gamma+\varepsilon_{\mathrm{it}}$

$y_{i t}$ is the measure for macro policy performance for country $i$ in year $t ;, y_{i t}$ is the output volatility measured as a five year standard deviation of the growth rate of per capita real output.

*TRI $\mathrm{i}_{\mathrm{t}}$ is a vector of any two of the trilemma indexes: MI, ERS and KAOPEN, and because we have shown that that the three measures of the trilemma are linearly related, it is most reasonable to include two of the indexes concurrently, not just individually nor all three collectively.

*IRi $\mathrm{i}_{\mathrm{t}}$ is the level of International Reserves (excluding gold) as ration of GDP, or STED or ED. Reserves level changes can potentially tell us something about how reserves are being used in practice to soften the trilemma tradeoff, particularly between exchange rate stability and monetary policy independence. 
* $T R \mathrm{Ri}_{\mathrm{t}} * \mathrm{IR} \mathrm{i}_{\mathrm{t}}$ is an interaction term between the trilemma index and the level of international reserves. Analyzing the effect of interaction term is very important because we suspect that IR may complement or substitute for other policy stances.

$X_{i t}$ is a vector of macroeconomic control variables that include the variables most used in the literature:

*Trade openness $((\mathrm{EX}+\mathrm{IM}) / \mathrm{GDP})$ : volatility in world good through trade openness may increase output volatility, according to Rodrik and Easterly $(1998)^{8}$ and Islam and Stiglitz $(2001)^{9}$.

*Relative income (to the U.S - per capita real income): there is a negative relation between the relative income and the output volatility, in fact it is the higher the level of income is (relative to USA

*M2 growth volatility (yearly standard deviations of M2 growth);

* Private credit creation as a ratio to GDP as a measure of financial development: as a measure of financial development: countries with more developed financial markets may suffer less from output volatility according to Aghion et al (1999), and Caballero and Krishnamurthy (2001). In fact an economy with more developed financial market is able to mitigate output volatility, maybe by allocating in a better way the capital. In or regression in Lebanon, the Private Credit to private sector is not taken because of data are given only from 1990.

*Inflation rate

*Inflation volatility as a five-year average of the yearly rate of inflation.

$\mathrm{Z}_{\mathrm{t}}$ is a vector of global shocks that includes:

*Change in US interest rate: the bigger change occurs on US real Interest rate, the higher output volatility may become on emerging countries or less developed countries because the US interest rate may indicate that the debt payment problem on these countries.

*World output gap a

*Relative oil price shocks (measured as the log of the ratio oil price index to the world CPI). The higher the shock is, the higher the output volatility countries experience.

This equation will allow us to compare two different ways of thinking about the impact of reserves and their interaction with the trilemma policy configuration, in affecting macroeconomic outcomes. Result and Interpretations are developed later.

\footnotetext{
${ }^{8}$ In Aizenman \& al (2008)

9 idem
} 


\section{Data}

All data are given quarterly by IFS-IMF and completed by the Central Bank of each country if needed. Yearly data are given by the World Bank.

Like Aizenman, Chin, Ito (2008, 2010), we use cross-country data and time-averages of annual data, so that their major source of variation is across countries. Except for Lebanon where we use data as a single country. Therefore, the data is higher frequency, being quarterly, and subject therefore to substantial time variation. Our period samples are divided into sub-period before and after crisis or big economic event.

We studied the subsample group for the full sample period: 1973 to 2010, as well as the subsample period that are divided by major economic event and crisis, such as the Mexican debt crisis in 1982, the Asian crisis of 1997-1998, and the Bubble crisis in 2001 that has affected developed and developing countries, combined with the Turkey debt crisis, and Argentina and Brazil Forex crisis. ${ }^{10}$

As for Lebanon, we are using a time series for a single country to estimate the trilemma configuration, and the period under consideration was a primordial change in external conditions as well as shifts in policy stances.

In a working paper (2006) entitled Identifying Structural Breaks in the Lebanese Economy ${ }^{11}$ 1970-2003: An Application of the Zivot and Andrews Test they found that structural breaks are identified in 1975 (beginning of the civil war), 1982 (Israeli invasion of Beirut) and 1988-1989 (Currency depreciation) and they don't identify any structural break after 90s. In our study we divide the entire sample period into two sub-periods: from 1973 to 1993 were the economy were suffering from instability due to a continuous was, and from 1994 to 2010 were the Lebanese economy recognized officially peace and new strategy. The Lebanese Government adopt a stabilization economic program (Sheikh S, 2006).

Thus we consider that Lebanon has only one structural break in 1993, where it was a click in the Lebanese in the last two decades. In this year, a new governor of the Central Bank was denominated and has adopted de facto a very fixed exchange rate, while the exchange rate were flexible, even during the 17 previous years of war (figure 3a). The Lebanese local currency became totally fixed. As shown in the Figure 3b in 1993, ERS becomes totally

\footnotetext{
${ }^{10}$ Aizenman, Chin, Ito (2008) invstigated the structural breacks of indexes and found that 1973, 1982, 1997-98, and 2001 are candidate structural breaks and are due to major event such as breakdown of the Bretton Woods system in 1973, the Mexican debt crisis of 1982 (indicating the beginning of 1980's debt crises of developing countries), and the Asian Crisis of 1997-98 (the onset of sudden stop crises affecting high performing Asian economies (HPAEs), Russia and other emerging countries

${ }^{11}$ Harvie C, Pahlavani M, Saleh A S; 2006.
} 
pegged to the American dollar and index $=\mathbf{1}$ and $\mathbf{K O}$ started to have an opposite trend decreasing from 1 to 0.6 over years from 1995: when ERS increases, KO decreases. Therefore, in our regressions, we apply a dynamic panel for all studied countries except for Lebanon where we apply a simple regression. 
Figure 3 a: The exchange rate regime of Lebanon over years.

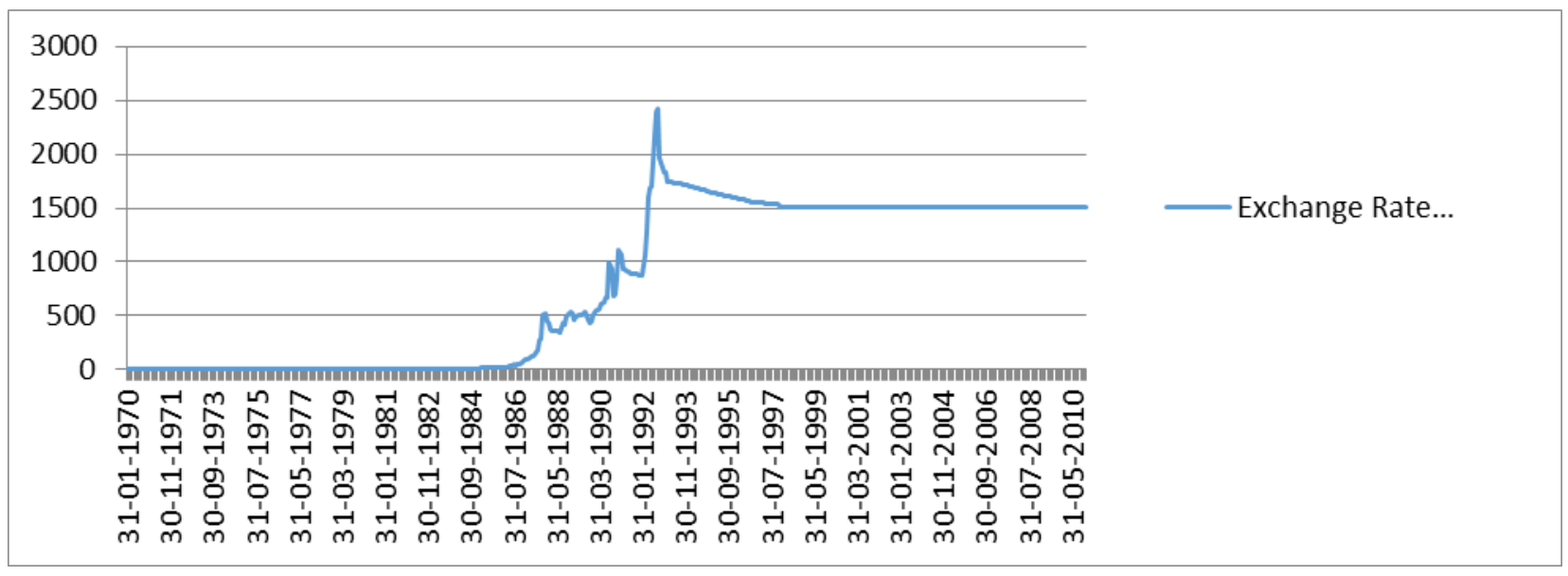

Figure $3 b$ - The evolution of the Lebanese Trilemma Indices over years

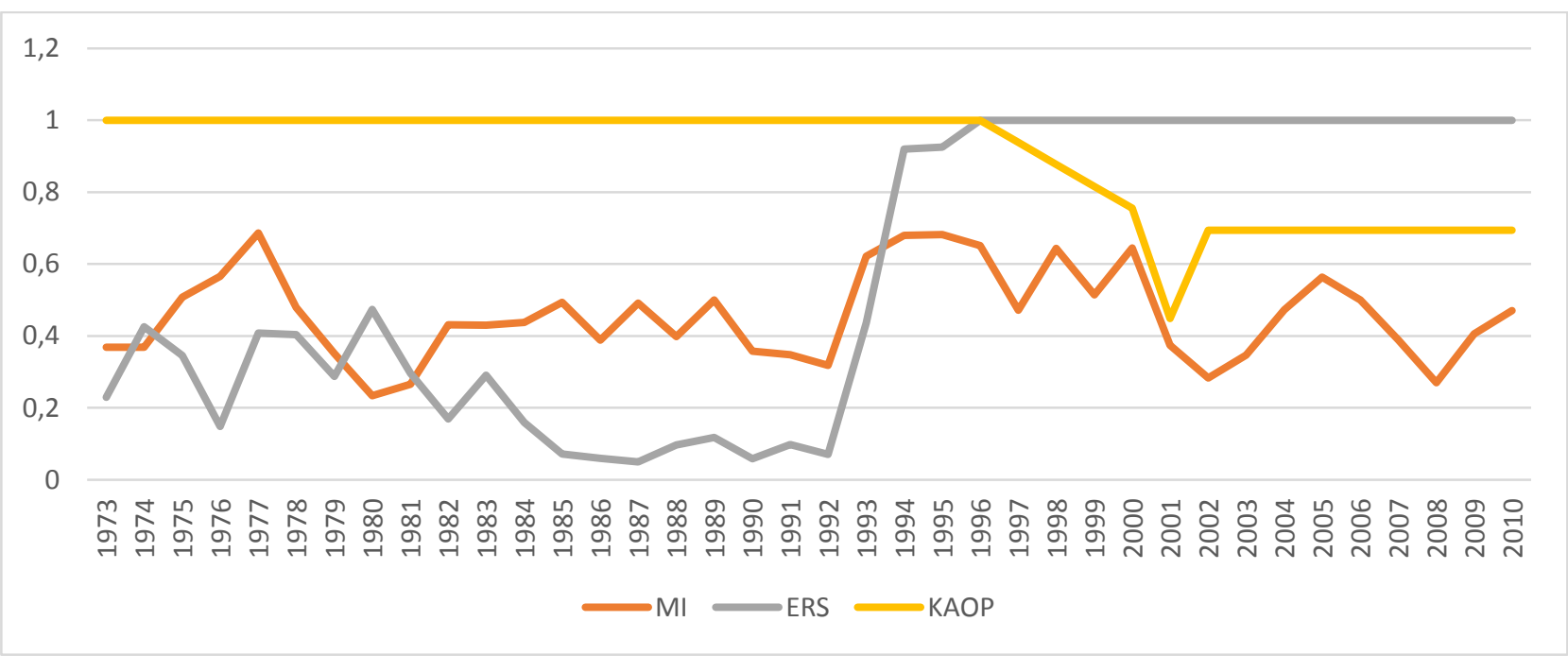

\section{Results and Interpretations}

This part discuss the results obtained from our analysis and its statistical interpretations of 1- Trilemma analysis of countries chosen, 2- quadrilemma analysis, 3- The Impact of (short term) external debt on output volatility of the economy.

\subsection{The Linear relation of the Trilemma analysis}

We estimated the triangle configuration by regressing a constant on the three indices. The results of difference in policies across different segment of year from 1973 to 2010 are reported in table 1 and table 2 at Annexes. The contributions reported in table 1 and 2 , are calculated by multiplying the coefficient by the mean for each subsample. 


\subsubsection{The trilemma analysis of Lebanon}

In the case of Lebanon, coefficients are not always estimated with great precision as Monetary Independence is not significant. But the overall fit extremely good, Capital Openness and Exchange Rate Regime are significant. In the same table, we have the Means reported. According to these measures, we can notice that before 1993, Capital Openness were the main interest policy in Lebanon before 1993. Since 1994, ERS becomes obvious, and adopting the fixed exchange rate de facto is clear. The mean of ERS increase from 0.2 to 0.99, thus we witness a whole change in the triangle Mundell like shown in Figure 4a. The contributions reported in table 1 , are calculated by multiplying the coefficient (of the regression) by the mean for each subsample. Their sum is almost equal to 2 (all are above 1.9) showing the strength of our result. Contributions can give some indications about the policy stance such:

- Capital Openness received high policy weight from 1973 till 1993 while it becomes almost neglected after 1993. The ERS that was underestimated before 1993 (-0.01411), becomes the main policy with the highest policy weight (1.8326) after 1993.

Figure 4a- The Linear Relation: Mundell Triangle of Lebanon

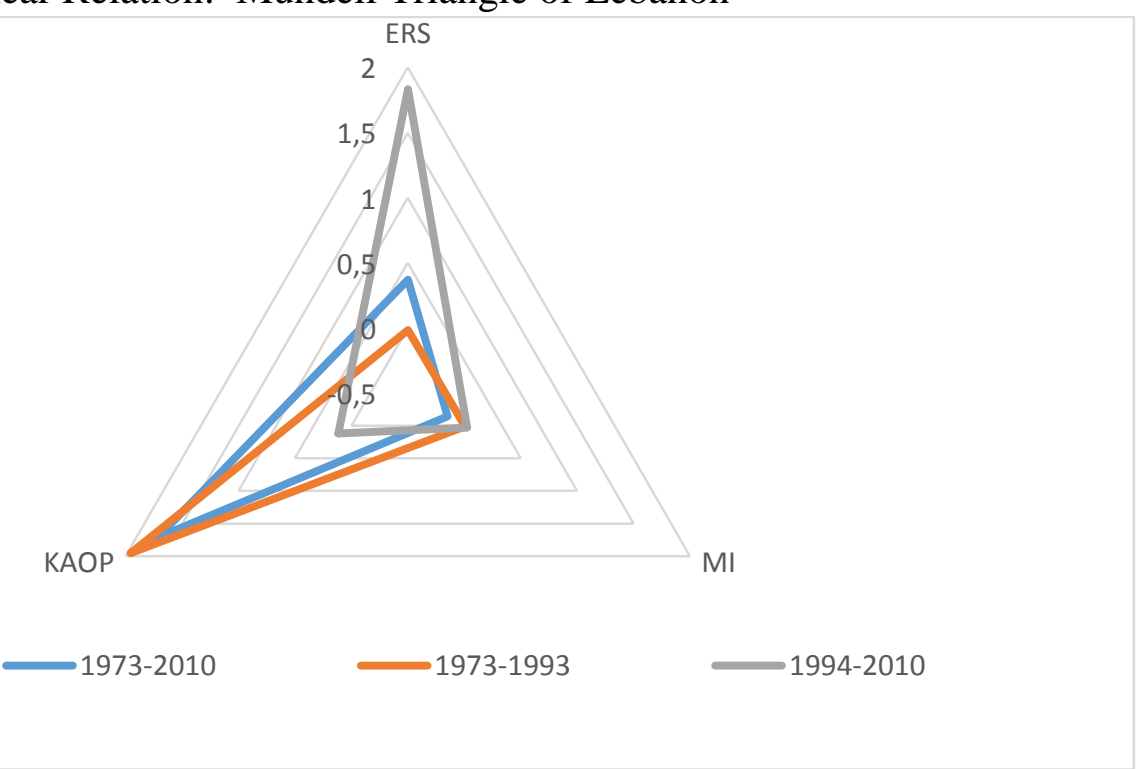

The Mundel triangle of Lebanon does not seem to be strange, it is predictable because we were expecting a change in the whole configuration of the Mundell triangle after 1993 since the new Lebanese Central Bank policy of fixing exchange rate without any fluctuation. 
What should be mentioned is that if we take the whole sample from 1973 to 2010 (blue triangle), the result might be biased because the triangle will show that Lebanese Government is encouraging the Capital Openness, while by dividing the sample into 2 subsample, we had an opposite result where the triangle (gray triangle changes (almost $90^{\circ}$ ) from one side to other side to apply primarily a fixing exchange rate. The results of table 2 seem to be consistent of the broad outline of what happened in Lebanon, as mentioned earlier.

As mentioned in previous study (Mansour 2012), the financial dollarization rate of Lebanon exceeds the $70 \%$, therefore, the Lebanese monetary authority are facing difficulties to even think about floating exchange rate regime. As explained by Calvo and Reinhart (2001) and Braga et al (2001), the is a strong relation between the "fear of floating" and the level of dollarization rate. The highest the dollarization rate is, the lowest is the degree of floating exchange rate regime, and the highest the "fear of floating" is expressend. This latter could be so acute that the exchange rate remains fixed long long time.

\subsubsection{The trilemma analysis of the Turkey, Argentina, Brazil and Mexico}

In the case of the group of countries sample, results and interpretations seem to be different. All coefficients are significant. As well as for the sum of contribution where they are all near two, above 1.8. Contributions indicates the variations of priority policies over years, is shows that Monetary Independence shared the highest weight all over the years from 1973 to 2001 and from 2002, the highest weight of contribution was for the exchange rate stability. As for the Capital Openness, it shared the lowest weight all over years. We report our result in the following triangle of figure $4 \mathrm{~b}$ below. 
Figure 4b- The linear relation: Mundell Triangle of Turkey, Argentina, Brazil and Mexico.

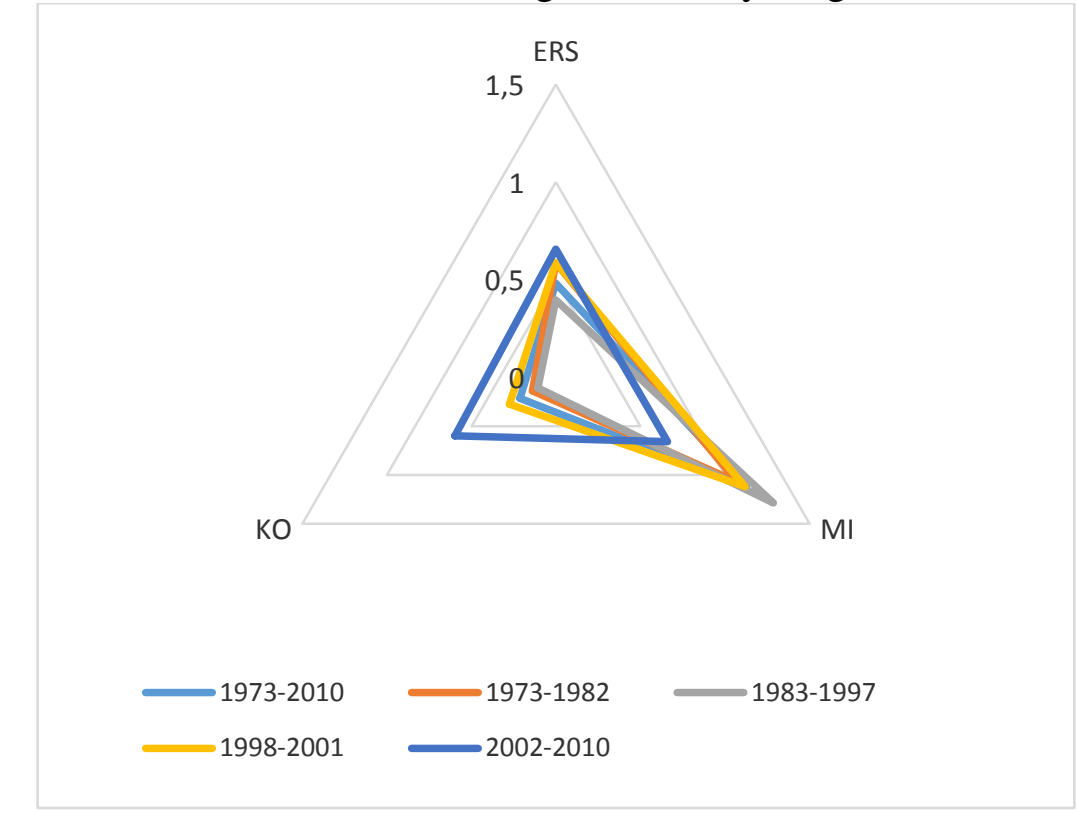

The figure shows clearer how the combinations of the trilemma policy choices are changing.

Unlike the case of Lebanon where the policy mix was not possible, in this panel case, with years, according to different sub periods, we can notice that the shape of the triangle is changing to increase the degree of the ERS by decreasing the degree of the MI (triangle gray, then triangle yellow then the green one) and increasing the degree of $\mathrm{KO}$.

This case shows clearly the changes of the Trilemma indexes over years, geometrically, the triangle see to be equilateral which lead to confirm our conclusion that emerging countries are adopting simultaneously three objectives.

Although these countries are dollarized and are expected to express the "fear of floating”, but these countries already challenged the fixed exchange rate regime in 90s and 2000s, and already broke the barriers and float their exchange rate regime and suffered long time from financial crisis do to their unsustainable policy. Nowadays, they are increasing IR in order to keep floating and keep opening financial market.

Our results are consistent with the figure $2 \mathrm{a}$ of Aizenman (2008-2010). In fact, the global view from 1973 to 2010 in blue indicates that the main monetary policy is adopting the monetary independence and exchange rate stability, renouncing the capital openness. If we take every period, from 1973 to 1982, from 1983 to 1997 and from 1998 to 2001, we notice that unlike in Lebanon, those countries were adopting first the MI and then the ERS first 3 subperiod and at last from 2002-2010, consistent with our result in table 2, countries were 
adopting a managed flexible exchange rate regime where RS, MI and KAOP are sharing almost the same average contribution (0.6)

\section{From the trilemma to the quadrilemma}

As we have discussed above, accumulating IR may give facilities to policy maker to deal with the trade-off between MI, ERS and KAOP. This has been examined in the regression reported in table 3 and 4 . We then report table results in the diamond graph below in order to see clearer the evolution of the policy decisions while introducing the IR

Unlike previous study mainly done by Aizenman \& al (2008), we repeat three times each calculations, by introducing the IR/GDP, then IR/ED and IR/STED in order to deduce if external debt can affect the IR in challenging the Mundell trilemma.

Result concerned in one hand a single country Lebanon, and in other hand a group of 4 countries

\section{*The quadrilemma of Lebanon}

According to table $3 \mathrm{a}$ to $3 \mathrm{~d}$, we can see that our coefficient are significant, except for the MI, like in the case of calculating the linearity in trilemma indexes above. But the result seems to fit well as long as $\mathrm{R}^{2}$ are higher and the sum of contributions are close to 2 (above $1.9)$.

It is important to mention that when IR is significant, it has a negative sign, what mean that IR does not contribute to any change in the monetary decisions of the Lebanese authority concerning the challenge of impossible trinity. As for other indices, we conclude like previous conclusions with trilemma indexes, that before 1993, the main policy where to encourage the capital openness, while the policy becomes primarily maintaining the exchange rate stability after 1993, whether IR or not, and whatever is the IR ratio.

The case of Lebanon is a perfect example to show that even if a country is accumulating a high level of IR like the case of Lebanon where the IR/GDP is one of the highest in the world (figure 4 in the Annex), if the policy maker does not allow the IR to intervene in challenging the Mundell Trilemma, the IR will have no effect on it. Whatever is the ratio of measurement of IR, whether it is over GDP or over ED or STED”. Table 3b-3c-3d in Appendix show that value of each goal is quite similar in all case from 1977-1393, indexes ERS and MI are around 0 while KAOP is about 1.89. from 1994 to 2010, the MI and KAOP becomes around 0 while ERS becomes the main objective and about 1.8-1.9, and IR does not play effective role in degree of monetary policies, it is always around 0 . Our results are reported below, in following figure $5 \mathrm{a}$ to $5 \mathrm{c}$. 
The Power of International Reserves : the Impossible trinity becomes possible

Figure 5a- The Trilemma including the IR/GDP

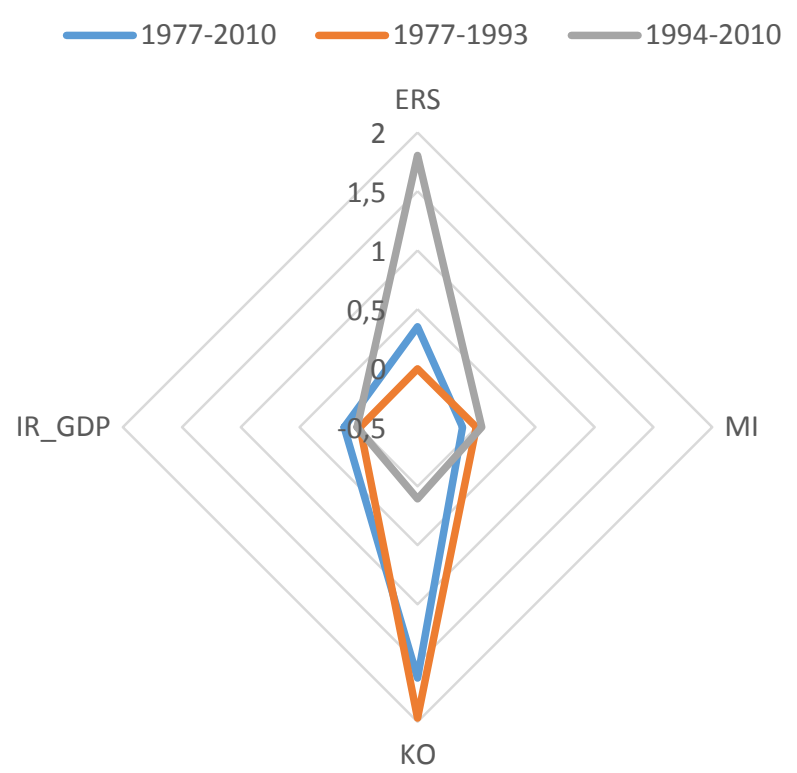

Figure 5b- The Trilemma including the IR/ED

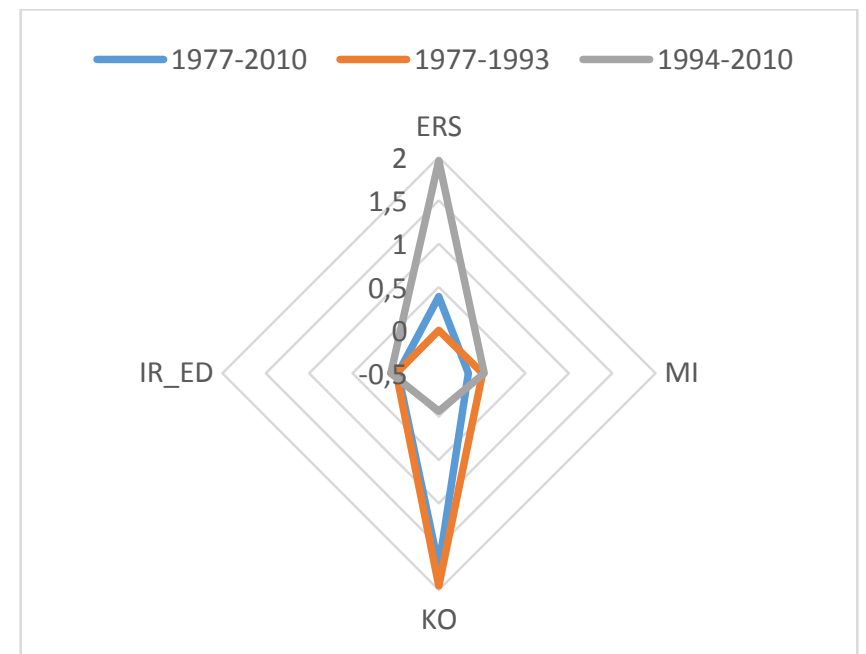

Figure 5c- The trilemma including the IR/STED

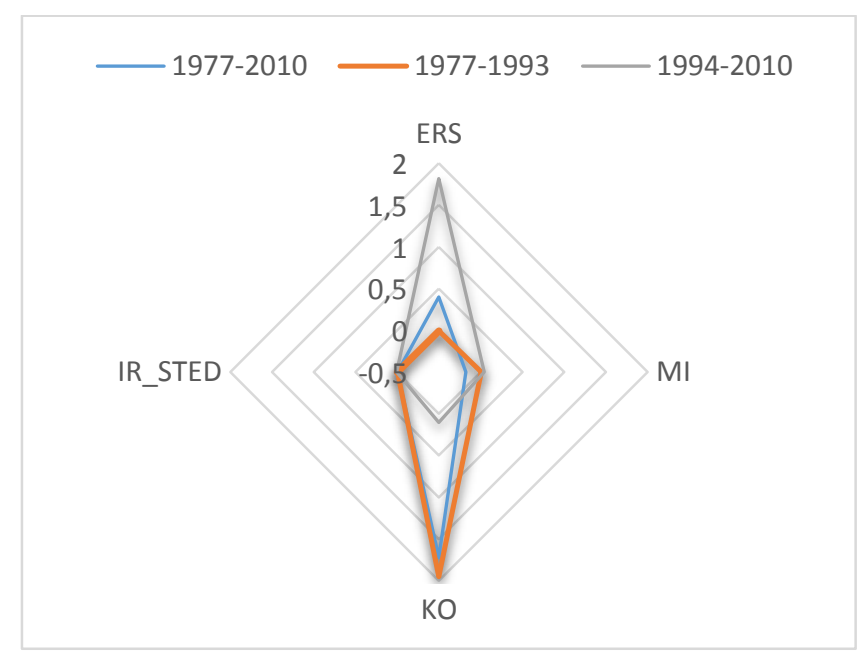


*The quadrilemma of Turkey, Brazil, Mexico and Argentina

Unlike the previous case, the case of Lebanon, the IR in the case of Turkey, Brazil, Mexico and Argentina seem to "act" like supposed theoretically, and to be involved in challenging the Mundell trilemma to have a new configuration that look like a diamond chart. In addition, interpretations may change depending on the IR ratio, whether it is on GDP or ED or STED.

First, referring to results in table $4 \mathrm{a}$ to $4 \mathrm{~d}$ of annexes, we realize that most of coefficients are significant, as well as the sum of contributions are all above 1.8, except for one case where the sum of contributions is equal to 1.4 although the adjusted $\mathrm{R}^{2}=0.89$.

According to Means of indexes in table 4a, we can notice that the IR/STED increase remarkably while other are almost maintaining the same level. The contribution of IR/GDP were increasing all over the years from 0.37 to 1.17 in the last sub-sample date from 2002-2010, and other indexes are sharing the weight of about 0.2 to 0.4 .

As for the IR/Ed ratio in table $4 \mathrm{~d}$, we notice that the contribution is quite different than the IR/GDP. While the latter was sharing the highest weight of the indexes in the last 8 years, the IR/ED contribution was about 0.34 . Note that previous year, the weighted average of the IR/ED was slowly similar to IR/GDP. Finally, in table 4c, we notice that the contribution of IR/STED as well as IR/ED were increasing over year till 2002 and after that, decreased sharply from 1.7 to 0.59 and from 1.34 to 0.34 . Unlike the case of Lebanon, the intervention of IR as a policy tool, contribute clearly to change the trilemma configuration and change the degree of each policy: MI, ERS and KAOP.

Figure $6 a$ to $6 \mathrm{c}$ below show the difference between the combination of ERS, MI and KAOP in the presence of IR. The two last figures seem to be similar, so we conclude that the similarity of the effect of External debt, whether they are short term or not. In addition, we conclude that 1998-2001 countries were sharply increasing IR (IR/GDP or IR/ED or IR/STED), and that since 2002 , the configuration of the diamond changed totally while introducing the IR/STED or IR/ED.

We conclude that only when we consider the IR on external debt (figure 6b-6c), countries seem to achieve ERS, KAOP and MI, while, when considering the IR/GDP, countries seem adopt mainly the policy of hoarding IR, and not of achieving the 3 policy goals. 
The Power of International Reserves : the Impossible trinity becomes possible

Figure 6a- The Trilemma including the IR/GDP

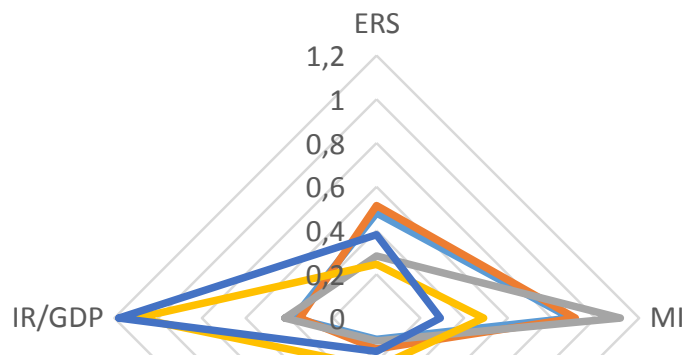

$\mathrm{KO}$

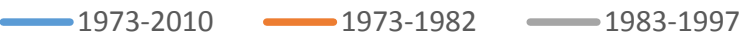

-1998-2001 2002-2010

Figure $6 b$ - The Trilemma including the IR/ED

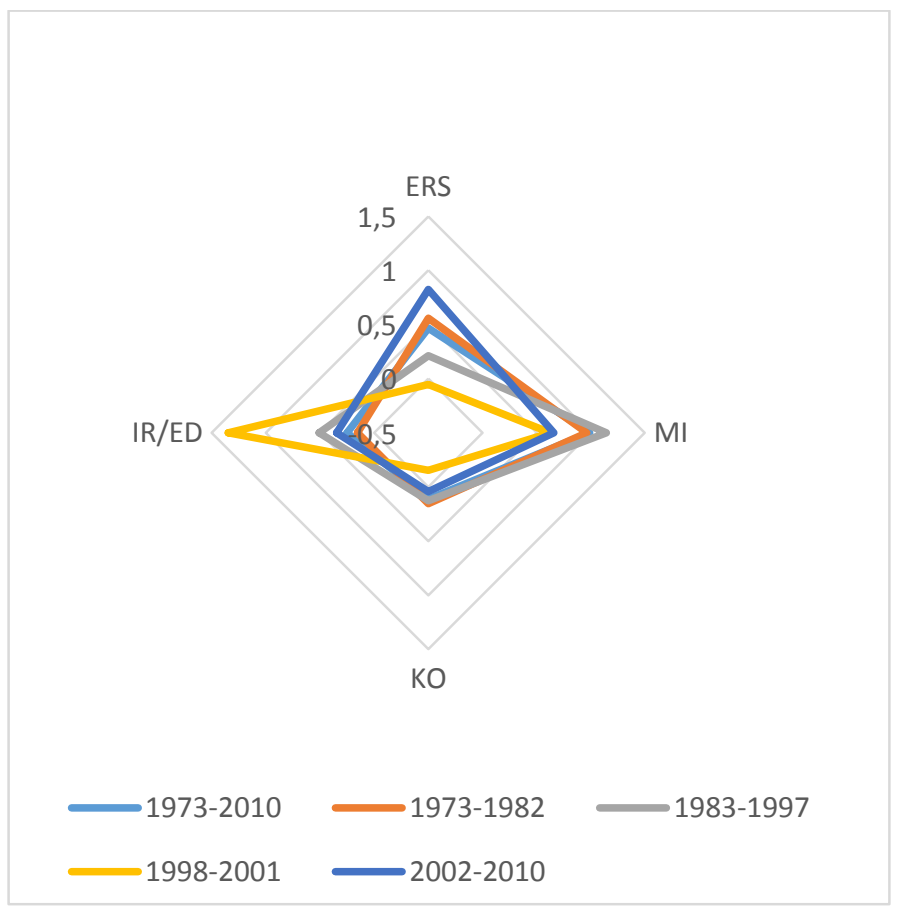


Figure 6c- The Trilemma including the IR/STED

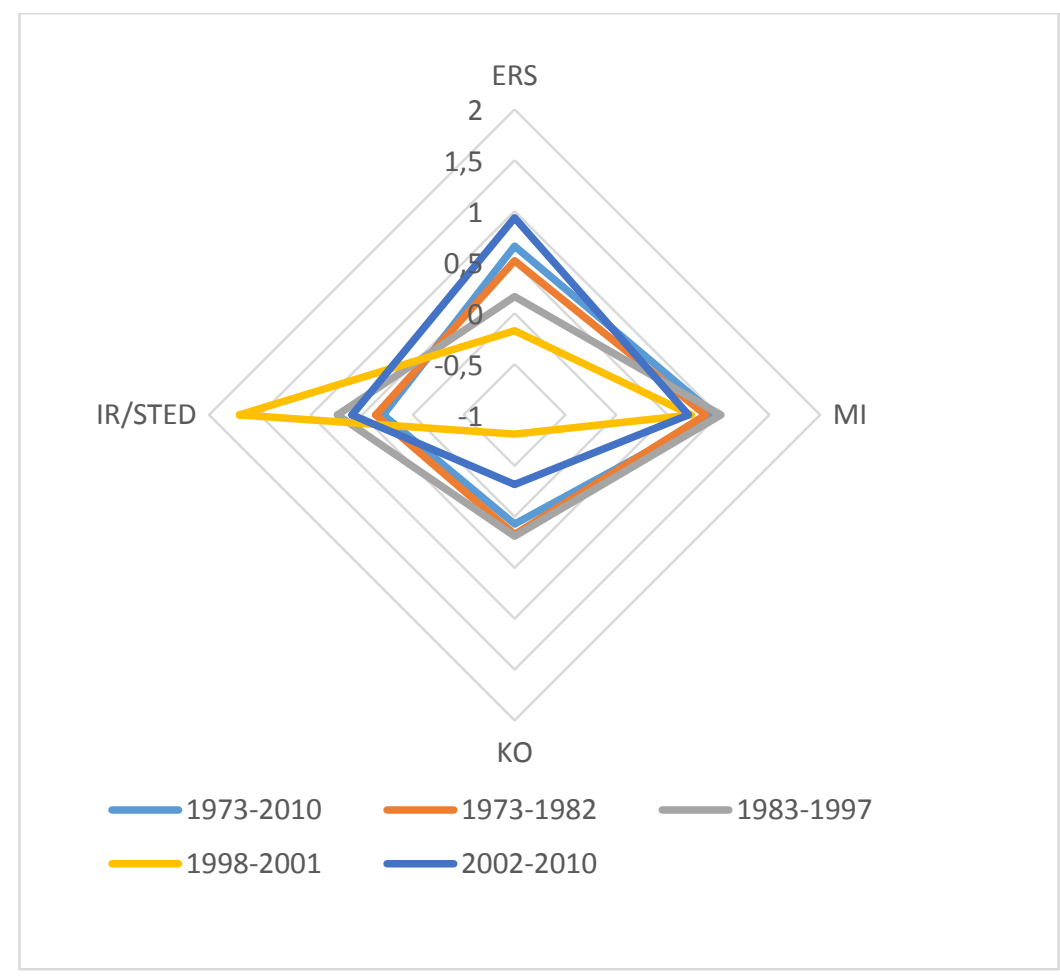

\section{The Impact of external debt and short external debt on monetary and decisions.}

The trilemma policy configuration and its interaction can be examined with the level of IR on the outcome volatility as mentioned above. Result of regressions are reported in Annexes, table 5a to 5c for the panel countries, and from table 6a to $6 \mathrm{c}$ for Lebanon. Each combination of two indices are reported in one column in addition of the interaction between one index and international reserve. Thus, each time we include IR whether it is over GDP or over ED or over STED, we repeat the regression 6 times (18 times for the panel and 18 times for Lebanon) in order to represent all possible combinations. Our results seem to be consistent and $\mathrm{R}^{2}$ are above 0.66 and significant coefficient have sign consistent with our expectation: the sign of coefficients are negative while we have a negative relation with the output gap volatility, and they are positive when the variable contribute to an increase of the output volatility. Interpretation will consist in parallel table $5 \mathrm{a}-\mathrm{b}-\mathrm{c}$ with $6 \mathrm{a}-\mathrm{b}-\mathrm{c}$ in order to make a small comparison between emerging country group that are adopting a flexible exchange rate regime with monetary intervention (managed), while Lebanon applied de facto a very strong fixed exchange rate regime.

First evident remark that can be given is that coefficient of Lebanon are bigger than coefficient of the Panel, which confirm the vulnerability of the output volatility of Lebanon comparing to other countries. 
Starting with control variables, such as the Relative Income (Per Capita GDP relatively to U.S), the coefficient of Lebanon is positively higher, knowing that the Lebanese relative income is lower, we conclude that the income is showing that the higher the lower income level, the higher output volatility is. The US real Interest rate is not significant in the Panel case. Like study of Cordahi and Goux (2007), the transmission of effect of US interest rate on Lebanon is not significant or very low. The positive sign indicates that it has a positive impact on the output volatility, because as cited above, it may represent a debt payment problem.

Trade openness is not significant in the Panel, but it is on Lebanon, suggesting that, according to Rodrik (1998) $)^{12}$ and Easterly, Islam and Stiglitz (2001) the trade openness lead to increase the output volatility. Some economists such Krugman (1993) and Razin and Rose (1994) detailed the type of trade openness (intra-industry or inter-industry) in increasing output volatility ${ }^{13}$.

The private credit creation is only reported in the Panel, not in Lebanon due to a lack of database. This variable that measures the financial development in the Panel is negatively significant and indicates that, consistent with Caballero and Krishnamurthy (2001) and Kose et al (2003), the developed financial market tend to reduce the output volatility.

Concerning the trilemma indexes, in the case of the Panel, according to table $5 \mathrm{a}$ to $5 \mathrm{c}$ of Annexes, we can notice that ERS seems not to be significant (except for only 2 regressions), meanwhile it is in the most of cases in Lebanon according to table 6a to 6c, thus, Exchange Rate Stability in Lebanon weaken the output volatility because of its negative sign, suggesting that country with strongest ERS will experience lower level of output volatility. ERS does not seem to be significant in the case of the Panel, but if it is coupled with the high International Reserves, ERS might have effect on the output volatility. Interaction term between ERS and IR (different ratio) have different results. Tables 5 and 6 show that interaction between the trilemma index and the IR is significant in the case of the Panel and in Lebanon (except while taking IR/ED for both Lebanon and Panel). It is important to mention that the sign is different in both cases: for the Panel, the sign is positive, showing that the interaction between the IR and the ERS increase the output volatility, while for Lebanon, the sign is negative it reduces the output volatility suggesting that countries holding International Reserves while maintaining a high ERS is able to reduce the output volatility which explain the trend of Lebanon to increase hoarding International Reserves.

\footnotetext{
${ }^{12}$ In Aizenman (2009)

13 idem
} 
In the case of the Panel in table 5, we see that KAOP is significant and its negative sign indicates that the higher the capital openness is, that lower the output volatility, unlike the case of Lebanon, where table 6 indicates that the higher the capital openness is, the more vulnerable the output volatility due to its positive sign. But in all cases, while coupling the KAOP with IR/GDP or ED or STED, only the ration IR/ED and IR/STED are significant, indicating that IR/GDP might be weak as variable comparing to other 2 ratios while interacting with the KAOP. The coefficients on the interaction term between the KAOP and the IR/ED or IR/STED are significantly negative indicating that countries hording IR may express less output volatility. Our result seem to be more consistent that results of Aizenman (2009), where he found negative relation between the interaction of KAOP and the IR, treating it as "result somewhat counterintuitive".

Table 5 and table 6 in Annexes show that the Monetary Independence is positively significant, suggesting that, unlike the result of Aizenman (2009), the greater the MI is, the higher the output volatility. If our results seem to be odd, it is consistent with result of Alesina and Summer (1993) who found that Independent Central Bank have no or little impact on output volatility. Concerning the interaction between the MI and the IR over GDP or ED or STED, only Lebanon seems to present coefficient negatively significant, suggesting that hoarding IR while interacting with MI reduces the output volatility, which lead to the understanding of the high trend of hording IR in Lebanon.

Other institutional development variables are not included in our model but could have impact on the reducing or increasing the output volatility such as the LEGAL which is composed of Law and Order (LAO), anti-corruption measures (CORRUPT) and bureaucracy quality (BQ).

\section{Summary}

This paper discussed the importance of hoarding International reserves in decision of monetary authority over years for countries that are accumulating International Reserves and exceeding external debt (in foreign currencies) at the same time; such Lebanon (studied separately), Argentina, Brazil, Mexico and Turkey (panel). The study was divided into three steps.

We started first by measuring and drawing the trilemma indexes/triangle over years in order to see visually the trend of each policy. It was shown that the trilemma indexes of the panel was changing progressively over years in a way not to keep the MI of the head of policies, but to achieve all of the objectives without renouncing to anyone. In other way, the 
decrease of MI was compensating by the increase of ERS, and the increase of KAOP and the triangle seem to be more equilateral than previous years: Thus, practicing the managed exchange rate regime. As for Lebanon, the trend changed from an extreme to another extreme: from achieving the KAOP as primary goal, to achieving the ERS, without any progressive change, which lead to confirm that the change was not due to a long term strategy or long term monetary policy, but due to a to an event, to a decision and brutal practice. Such result was expected as Lebanon is practicing (de facto) a total fixed exchange rate regime.

Second, we introduced the IR (IR/GDP, IR/ED and IR/STED) in order to see the impact of hoarding International Reserves on monetary decisions in the context of Mundell trilemma. We found obviously that taking the ratio IR/GDP gives totally different interpretation than IR/ED and/or IR/STED in the case of the Panel. The two latters give more sense and gives explanation that hoarding IR according to the level of ED or STED leads monetary authority to achieve the three goals, with more or less similar degree (little MI, little ERS and little KAOP) thus, we conclude that hoarding International Reserves becomes a mean for monetary authority to apply simultaneously the three goals of the Mundell Trilemma. The ration IR/GDP shows totally different interpretation; we notice that hoarding IR/GDP becomes no more a mean of achieving goals, but simply becomes the main goal and main objective by renouncing to the MI, ERS and KAOP. As for Lebanon, the IR level has no different effect whether it is measured over GDP or ED or STED. This makes our previous conclusions stronger, that hoarding IR is independent for monetary decisions toward the three policies of the Mundell triangle, in other terms, the IR in not included or does not play any economically role in terms of monetary policies, it could be explained only by that increasing IR could be an auto insurance against future probable crisis due to sudden stop, or flight of money of dollarization rate or other, but not a tool to change the Mundell Triangle. Lebanon could be an example of country where according to $\operatorname{IMF}^{14}$ (2011), reserves may be accumulated or held for non-precautionary reason, like due to exchange rate policy or for intergenerational.

Finally, by observing the Impact of different International Reserves ratio on Output Volatility and Interaction between IR ratio on GDP or ED or STED with trilemma indexes, we found that first of all, IR whether measured over GDP or ED or STED doesn't necessarily have difference conclusion on the output volatility like it is while measuring the degree of each policy in the trilemma/quadrilemma. Consistent with Aizenman et al (2008) results,

\footnotetext{
${ }^{14}$ IMF, 2011, assessing Reserve Adequacy
} 
regressions show that, the higher the ERS and the IR a country follows, the more negative impact it can have on output volatility. The Interaction between IR and ERS have opposite impact on the output volatility, it increases the output volatility in the Panel and decreases in Lebanon thus, the highest level of ERS and IR, the more negative impact it can have on output volatility. KAOP has opposite impact on the output volatility. Countries with more or less flexible exchange rate regime such the Panel, the KAOP decreases the output volatility, unlike Lebanon where KAOP increase the output volatility. In both cases, the KAOP coupling with the IR is significant only while taking the IR/ED or IR/STED, indicating that the IR/GDP is a weak variable to be considered with KAOP. I addition, the IR interacted with the KAOP lead to decrease the output volatility, thus IR is able to mitigate the output volatility. The MI indicates a positive impact on the output volatility for both cases. When coupling the MI with the IR, we remark that only in Lebanon we significant impact on the output volatility and opposite result, suggesting the importance of IR in reducing the output volatility. 


\section{Conclusion}

Although empirical studies of Bubula and Otker-Robe (2003) shows that intermediate solution is vulnerable to financial crisis, focused on the advantage and cost of every corner solution especially in emerging countries after 90s financial crisis, he concludes that a corner solution would not be preferable, but an intermediate regimes seem to be a better solution (Allegret 2007), especially for emerging countries where their structural characteristics are: debts, external debts (in foreign currencies), financial vulnerability; and low domestic institutional infrastructure (domestic governance approach (Allegret 2005)). In this paper we evaluate the impact of International Reserves ratio over GDP or ED or STED in two scenarios: the first one is assessing the IR on the monetary policy (ERS, MI, KAOP) of monetary authorities by studying the trend and changes patterns of the Trilemma configuration over years, and the second is evaluating its impact on the output volatility with monetary policy (ERS, MI, KAOP) as well. Our study is based on countries that are hoarding International Reserves and suffering from external debt (in foreign currency) such as Argentina, Brazil, Mexico and Turkey who adopted a (managed) flexible exchange rate regime, and Lebanon who "obliged" to adopted de facto a fixed exchange rate regime (corner solution) because of its high dollarization rate. We conclude first that IR participate in changing the patter of the Mundell Trilemma of emerging countries which lead to the "possible trinity" or a new configuration called Quadrilemma. These countries accumulate high levels of IR in order to achieve certain level of exchange rate stability and financial openness together while maintaining high levels of monetary independence, and every goal has been achieved with an equal degree. It was tested that countries faced the trade-offs based on the trilemma and we confirmed that change in one of the trilemma variables would induce a change with the opposite sign in the weighted average of the other two. As for Lebanon, the IR does not participate to monetary decisions, that is, monetary authority does not include the IR to change the trend of achieving goals of the Mundell Trilemma. This latter is already decided and applied whether there is IR or not. That is, in the case of Lebanon, IR ratio measured on GDP or on debts do not change our result.

Finally, we examined the impact of policy orientation which two out of three policies to choose, on output volatility and we found that taking IR/ED and STED is not or quite more significant than taking IR/GDP, and we conclude that coupling IR with trilemma indexes have impact on output volatility in all countries, although with opposite direction or interpretation. 


\section{References}

- Aghion P, Banerjee A, Piketty T; 1999; Dualism and Macroeconomic Volatility; Quarterly Journal of Economics, Vol. 114, pp. 1359-97.

- Aizenman J, Ito H; 2012; Trilemma policy convergence patterns and output volatility; NBER Working Paper $\mathrm{N}^{\circ} 17806$.

- Aizenman J; 2010; The impossible trinity (aka the policy trilemma); the encyclopedia of financial globalization.

- Aizenman J; 2009; On the paradox of prudential regularitions in the globalized economy; International Reserves and the Crisis: a Reassessment; NBER Working Paper $\mathrm{N}^{\circ} 14779$.

- Aizenman J, Chinn M D, Ito H; 2008; Assessing the emerging global financial architecture: measuring the trilemma's configurations over time; NBER $\mathrm{N}^{\circ} 14533$.

- Aizenman J, Glick R; 2008; Sterilization, Monetary, and Global Financial Integration; federal reserve bank of San Francisco working paper series, 2008-15

- Aizenman J, Marion N; 2004; International Reserves Holding with Sovereign risk and costly tax collection”, Economic Journal 114, pp 569-591.

- Aizenman J, Hausmann R; 2001; Exchange Rate Regimes and Financial-Market Imperfections; UCSC Dept. of Economics Working Paper No. 493.

- Aizenman J, Frenkel J; 1985; Optimal Wage Indexation, Foreign Exchange Intervention, and Monetary Policy ;The American Economic Review, 75/3, pp.402423

- Alesina A, Summer L; 1993; Central Bank Independence and Macroeconomic Performance; Journal of Money, Credit and Banking N²5, pp.191-214.

- Allegret J P; 2007; Quels régimes de change pour les marchés émergents ? les solutions de coins en questions ?; Original Scientific Paper, $N^{\circ}$ 4, pp 397-427

- Allegret J.P ; 2005 ; Les régimes de change dans les marchés émergents, quelle perspective pour le 21ème siècle ? Vuibert Edition, Paris.

- Allegret J.P, Sandretto R ; 2000 ; La nouvelle architecture du système monétaire international, revenir à l'esprit des lois de Bretton Woods », L'Actualité Economique, vol.76, N³, September, pp.437-456

- Arize A C, Malindretos J; 2012; Foreign Exchange Reserves in Asia and its Impact on Import Demand; International Journal of Economics and Finance, Vol 4, N³. 
- Atish R G, Gulde A-M, Ostry J, Wolf H C; 1997; Does the Nominal Exchange Rate Regime Matter?; NBER N5874

- Ben-Bassat A, Gottlieb D; 1992; Optimal International Reserves and sovereign risk; Journal of International Economics 33, p 345-62.

- Bergsten F, Davanne O, Jacquet P ; 1999 ; Pour une gestion conjointe de la flexibilité des changes ; in F. Bergsten et alli (eds), Architecture financière internationale, Rapport du Conseil d'Analyse Economique, ${ }^{\circ} 18$, La Documentation Française, Paris, p.9-54.

- Bird G, Rajan R ; 2003 ; Too Much of a Good Thing? The Adequacy of International Reserves in the Aftermath of Crises ; The World Economy 26, no. 6: 873-91.

- Bordo M D, Flandreau M, 2003 ; Core, Periphery, Exchange Rate Regimes, and Globalization ; NBER Chapters, in: Globalization in Historical Perspective, pages 417472

- Braga de Macedo J, Cohen D, Reinsen H ; 2001 ; Taux de change ni fixe ni flottant, édition OCDE

- Bubula A, Ötker-Robe I; 2002; The evolution of exchange rate regimes since 1990: evidence from de facto policies », IMF Working Paper, WP/02/155.

- Caballero R, Krishnamurthy A; 2001; International and Domestic Collateral Constrains in a Model of Emerging Market crisis », Journal of Monetary Economics, 48(3), p.513-548.

- Calvo G, Izquierdo A, Loo-Kung R; 2012; Optimal holding of International Reserves: Self-Insurance against sudden stop, NBER Working Paper №18219.

- Calvo G, Reinhart C M; 2000; When Capital Flows come to a sudden stop: consequences and policy. In reforming the International Monetary and Financial System, IMF

- Calvo G, Reinhart C.M; 2002; Fear of floating; The Quarterly Journal of Economics, vol.117, n², p.379-408.

- Calvo G A, Reinhart C M.. 2001. Fixing for Your Life. In Brookings Trade Forum 2000, edited by Susan M. Collins and Dani Rodrik. Washington, D.C.: Brookings Institution.

- Chinn M D, Ito H; 2008; A New Measure of Financial Openness; Journal of Comparative Policy Analysis, Volume 10, Issue 3, p. 309 - 322 
- Chinn, M D, Ito H ; 2006 ; What Matters for Financial Development? Capital Controls, Institutions, and Interactions ; Journal of Development Economics, Volume 81, Issue 1, Pages 163-192

- Chinn D. M, P. J. Miller; 1998; Fixing vs Floating Rates: a Dynamic General Equilibrium Analysis; European Economic Review 42, 1221-1249.

- Cook D, Yetman J; 2012; Expanding central balance sheet in emerging Asia: a compendium of risks and some evidence; bis paper $\mathrm{N}^{\circ} 66$

- Cordahi C, Goux J F; 2007, The International Transmission of Monetary Shocks in a Dollarized Economy: The case of USA and Lebanon; GATE w p series $\mathrm{N}^{\circ}$ 07-15

- Cortuk, O, Singh N ; 2011 ; Turkey's trilemma trade-offs: is there a role for reserves?; MPRA Paper 33887, University Library of Munich, Germany.

- Devereux M B, Engel C; 2003; Monetary Policy in the Open Economy Revisted : Price setting and Exchange Rate Flexibility, Review of Economic Studies, p.765-783

- Devereux M B, Engel C ; 1998; fixed versus floating exchange rate regime : how price setting affects the optimal choice of exchange rate regime; NBER working paper $\mathrm{N}^{\circ} 6867$

- Durdu C B, Mendoza E G, Terrones M E; 2007 ; Precautionary Demand for Foreign Assets in Sudden Stop Economies : An Assessment of the New Merchantilism ; NER Working Papr $\mathrm{N}^{\circ} 13123$

- Eaton J; 1985; Optimal and Time Management in an Overlapping Generation Economy; Journal of International Money and Finance 4, pp.83-100.

- Edison H J, Klein M W, Ricc L, Sløk, T; 2002; Capital Account Liberalization and Economic Performance: A Review of the Literature; IMF Working Paper.

- Edison H J, Warnock F E; 2001; A simple measure of the intensity of capital controls; International Finance Discussion Paper $N^{\circ} 708$

- Edwards S; 2001; Capital Mobility and Economic Performance: Are Emerging Economies Different?; NBER Working Paper No. 8076

- Eichengreen B, Kose K A, Wyplosz; 1996; Contagious Currency Crises; NBER $\mathrm{N}^{\circ} 5681$

- Frankel J, Schumkler S L, Serven L; 2004; Global transmission of interest ratesMonetary independence and currency regime; Journal of International Money and Finance, vol.23, N5, pp701-733. 
- Frenkel J and Jovanovic B ; 1981 ; Optimal international reserves: a stochastic framework. Economic Journal, No. 91 (June), pp. 507 - 14.

- Frankel A J; 1999; No single currency regime is right for all countries or all times, NBER, Working Paper Nº7338

- Friedman M; 1953; The Case for Flexible Exchange Rates, in Milton Friedman ed. Essay in Positive Economics, (Chicago: University of Chicago Press).

- Glick R; 2010; The illusive quest: Do International Capital Control Contribute to Currency Stability?; Federal reserve Bank of San Francisco, Working Paper 2010-15

- Harvie C, Pahlavani M, Saleh A S; 2006; Identifying Structural Breaks in the Lebanese Economy 1970-2003: An Application of the Zivot and Andrews Test.

- Helpman E; 1981; An Exploration in the Theory of Exchange Rate Regimes; Journal of Political Economy 10, 263-283.

- Hutchison M M, Sengupta R, Singh N; 2012, India's Trilemma: Financial liberalization, exchange rates and monetary policy, earlier version presented at the $7^{\text {th }}$ NIOFP-DEA Research Leeting held in New Dlehi september 2010.

- International Monetary Fund; 2011; Assessing Reserves Adequacy.

- Jeanne O, Rancière R; 2009; The Optimal Level of International Reserves for Emerging Market Countries: Formulas and Applications, IMF and CEPR.

- Jeanne O, 2007, International Reserves in Emerging Market Countries, too much of a good thing? Brookin Paper on Economic Activity, $\mathrm{N}^{\circ} 1$.

- Johnson H; 1969; The Case for Flexible Exchange Rates, Federal Reserve Bank of St Louis

- Kaminsky G L, Reinhart C M, 1999; The twin crises: the causes of banking and balance of paayment problems, The American Economic Review.

- Kose, M A, Prasad E and Terrones M; 2003; Financial Integration and Macroeconomic Volatility; IMF Working Paper WP/03/50. Washington, DC, United States: International Monetary Fund.

- Krugman P.R. (1998), « The eternal triangle », October http://web.mit.edu/krugman/www/triangle.html

- Lapan H. L, Enders W; 1980; Random Disturbances and The Choice of Exchange Rate Regimes in an Intergenerational Model; Journal of International Economics 101, 263-283. 
- Levy Yeyati E; 2008; The cost of reserves; Economics Letters, Elsevier, vol. 100(1), pages $39-42$

- Levy-Yeyati E, Sturzenegger F; 2002; Classifying Exchange Rate Regimes:Deeds vs. Words; Mimeo, Universidad TorcuatoDi Tella

- Mishkin, F. S, Savastano, M. A; 2001; A Monetary Policy Strategies for Latin America; Journal of Development Economics, World Bank Policy Research Working Paper No. 2685. Retrieved April 15, 2007 at SSRN.

- Mundell R A; 1963; Capital Mobility and Stabilization Policy under Fixed and Flexible Exchange Rates; Canadian Journal of Economics and Political Science 29, 475-485.

- Mundell R A; 1961b; Flexible Exchange Rates and Employment Policy; Canadian Journal of Economics and Political Science 27, 509-517.

- Mundell R. A; 1961a; A Theory of Optimum Currency Areas; American Economics Reviews 51, 509-517.

- Mundell R. A; 1960; The Dynamics in International Monetary Adjustment under Fixing and Floating Exchange Rates; Quarterly Journal of Economics 74, 227-257.

- Obsfeld M, Schaumbaugh J C, Taylor A M, 2009, Financial Instability, Reserves, and Central Bank Swap Lines in the Panic of 2008, NBER Working Paper, $\mathrm{N}^{\circ} 14826$.

- Obsfeld M, Shambaugh J C, Taylor A M; 2008; Financial Stability, The trilemma and International reserves; NBER Working Paper $N^{\circ} 14217$.

- Obsfelt M ; 2006 ; Pricing to Market, The Interest Rate Rules and the Exchange Rate, NBER N 12699

- Obsfeld M, Schambaugh J C, Taylor A M, 2004; Monetary Sovereignty, Exchange Rates and Capital Controls: The Trilemma in the Interwar Period, NBER Working Paper, $\mathrm{N}^{\circ} 10393$

- Obsfeld M, Shambaugh J C, Taylor A M; 2004, The trilemma history: Tradeoffs among exchange rates, monetary policies and capital mobility; NBER Working Paper $\mathrm{N}^{\circ} 10396$.

- Obstfeld M, Rogoff K ; 1995 ; The intertemporal approach to the current account ; Handbook of International Economics, edition 1, volume 3, chapter 34, pages 17311799 Elsevier. 
- Ortiz J, Rodriguez C; 2002; Country Risk and the Mundell-Fleming Model applied to the 1999-2000: Argentina Experience; Journal of Applied Economics, Vol. V, No. 2 p.327-348.

- Popper H, Mandilaras A, Bird G; 2011; Trilemma Stability and International Macroeconomic Arcgetypes

- Reinhart C M, Rogoff K S; 2004; The Modern History of Exchange Rate Arrangements: A Reinterpretation;Quarterly Journal of Economics, Vol CXIX, Issue 1

- Ripoll L ; 2001 ; Choix du régime de change: quelles nouvelles ; Université de Montpellier I.

- Rodrik D; 2006; The Social Cost of Foreign Exchange Reserves; NBER N 11952.

- Rogoff K; 2004 ; Extending the limits of global financial integration, Journal of Policy Modeling, p.519-523.

- Sheikh S; 2006; Exchange Rate-Based Stabilization in War-Ravaged Economies: The Case of Lebanon; Monetary Institute of International Studies

- Summers L. H. 2006. "Reflections on Global Account Imbalances and Emerging Markets Reserve Accumulation.” L. K. Jha Memorial Lecture, Reserve Bank of India. 


\section{Annexes}

Figure 1- Main role expected by Hoarding International Reserves

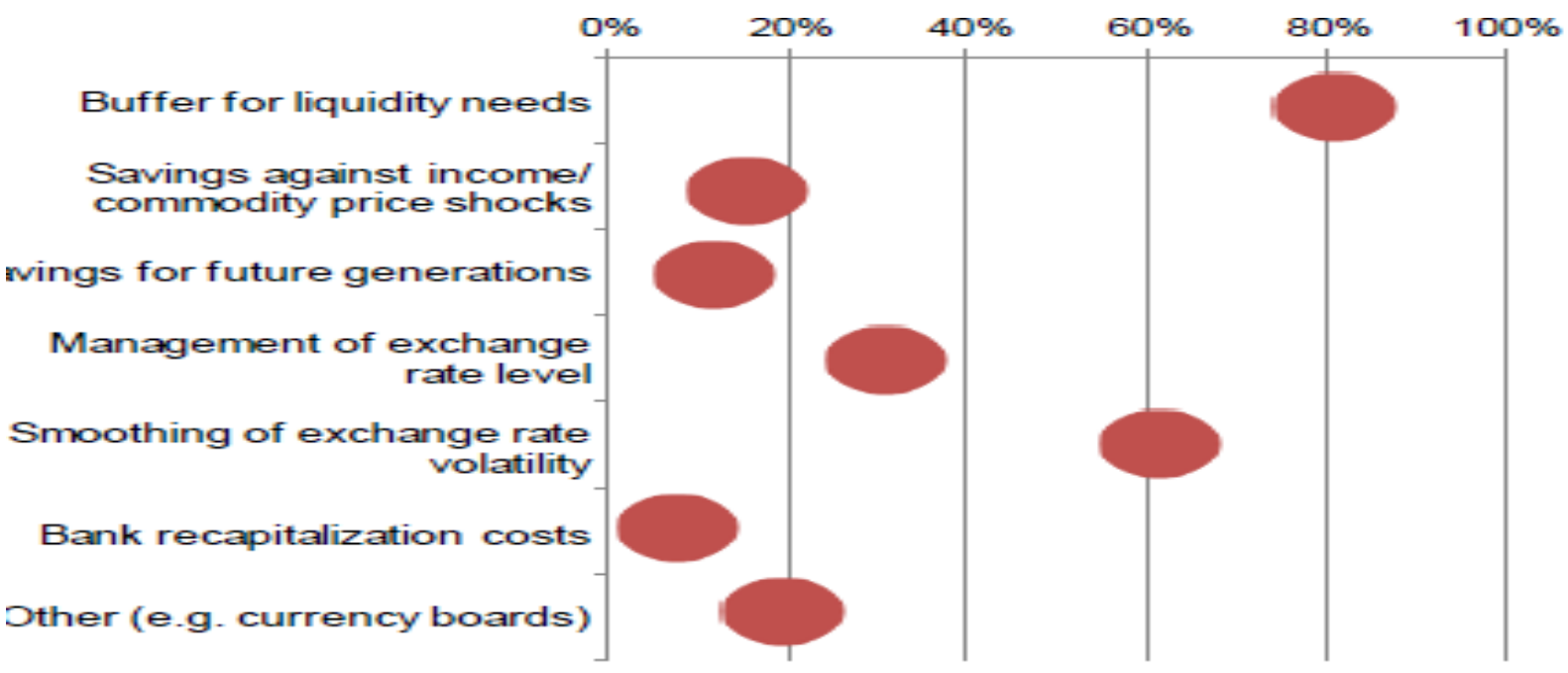

Source: IMF survey of Reserve Manager

Figure 2a - Trilemma Indexes of Brazil

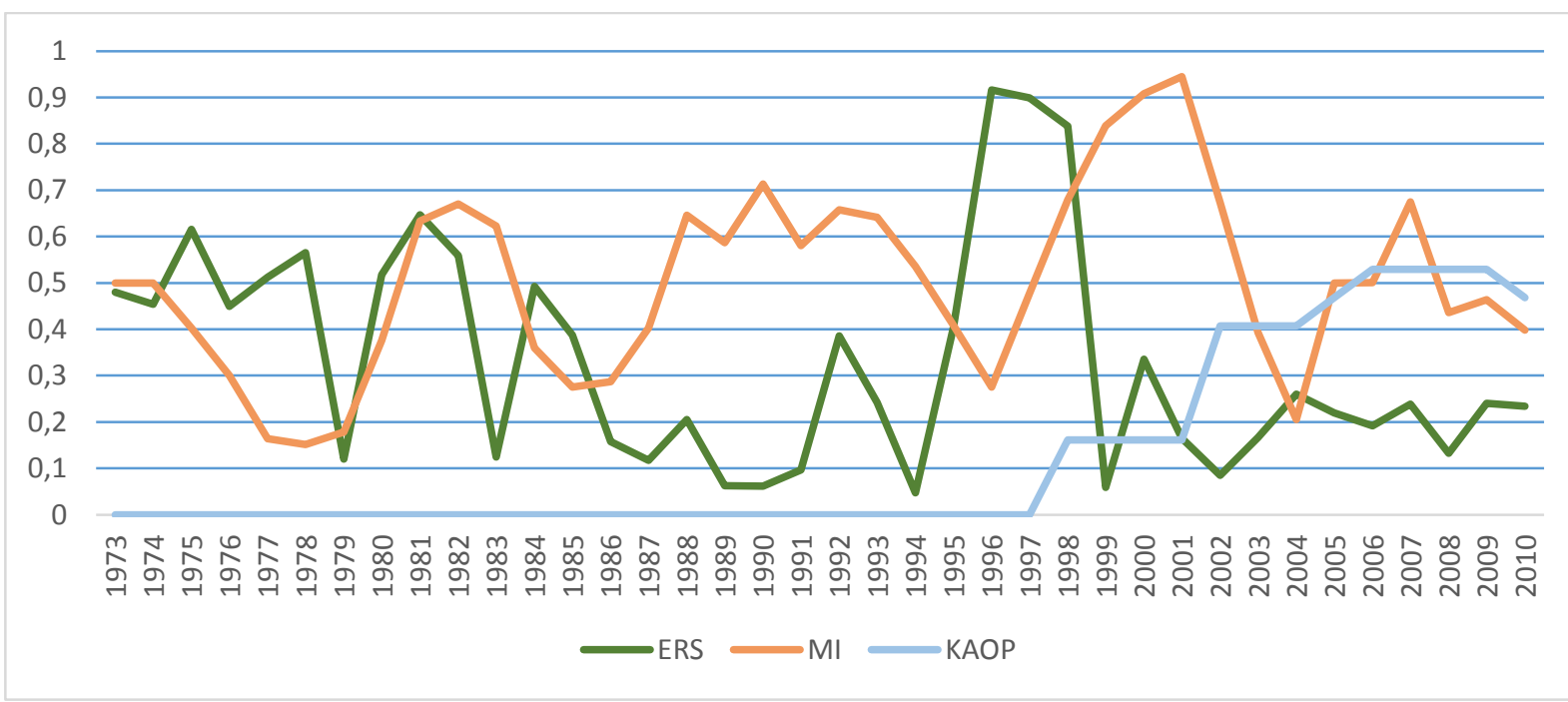


Figure 2b- Trilemma Indexes of Mexico

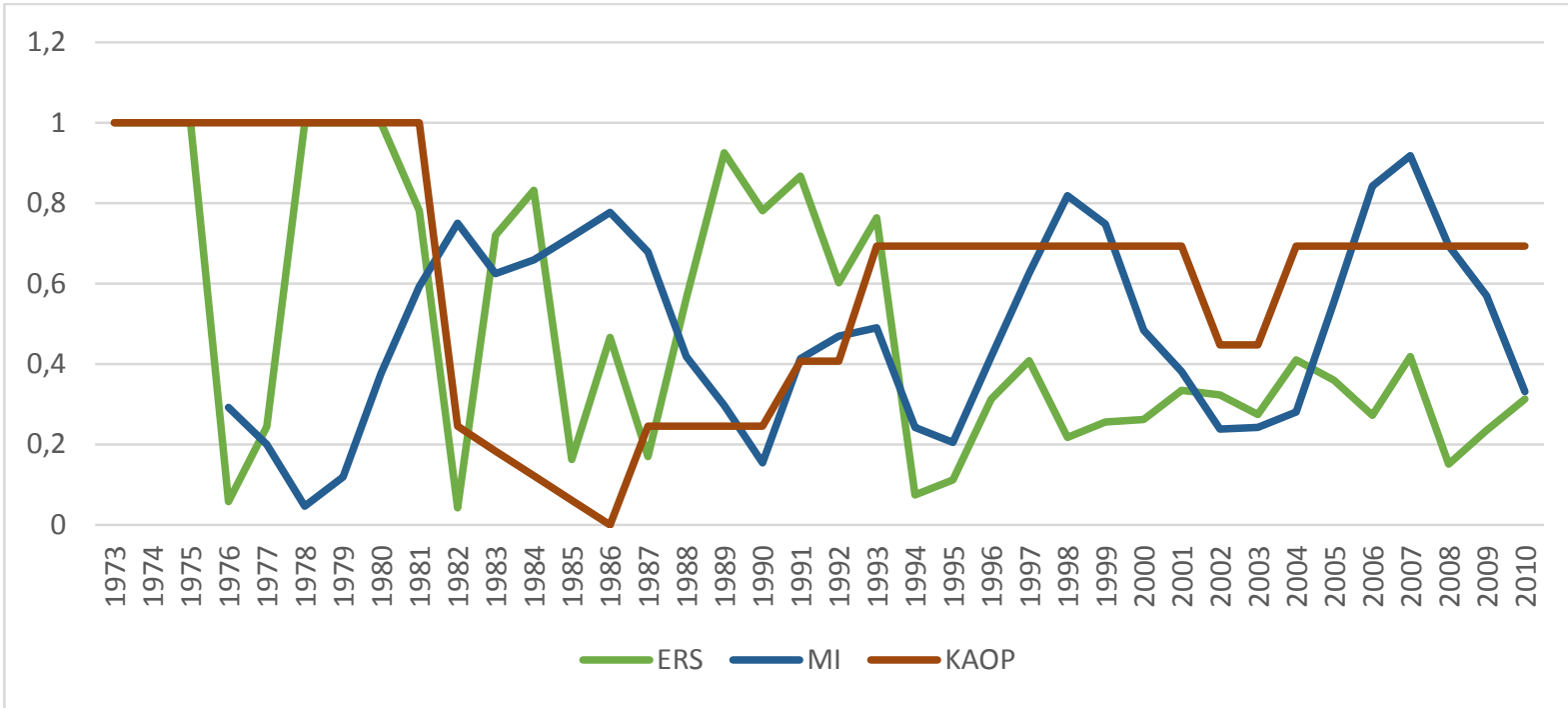

Figure 2c- Trilemma Indexes of Turkey

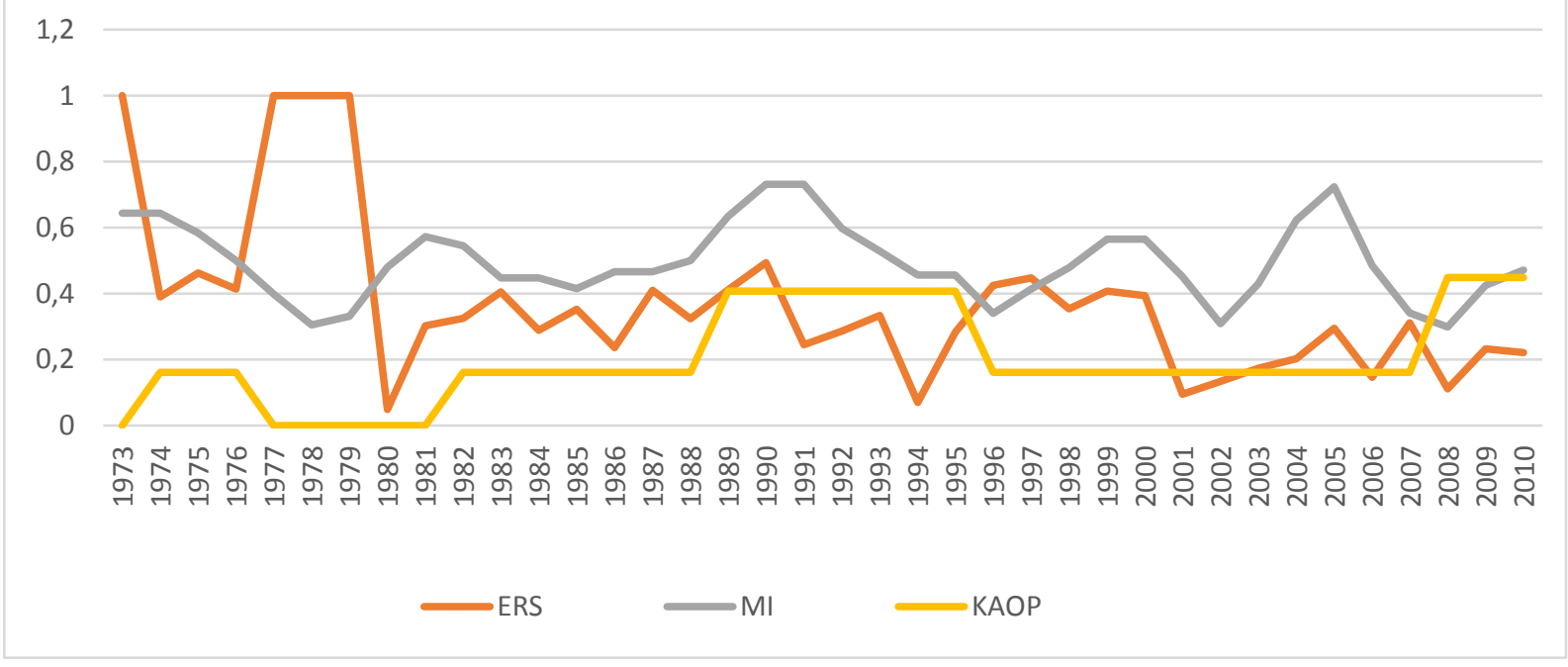


Figure 2d- Trilemma Indexes of Argentina

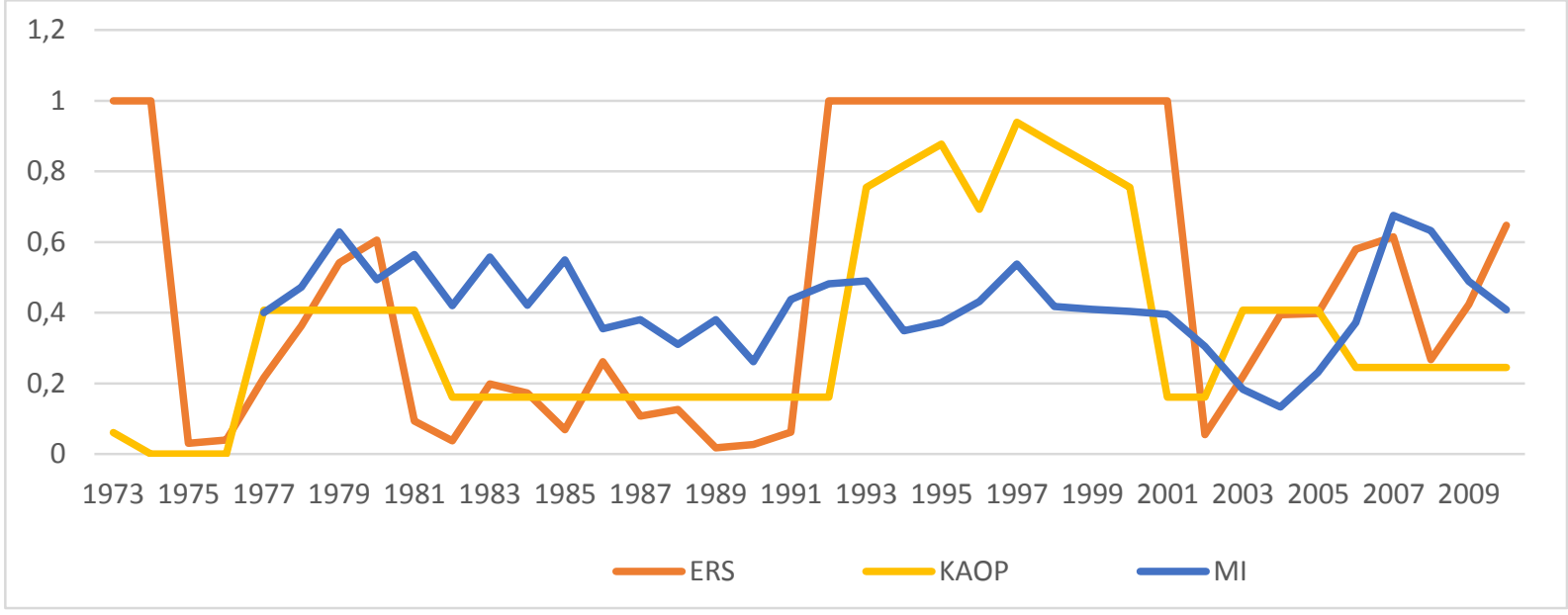

\section{Figure 2e- Trilemma Indexes of Lebanon}

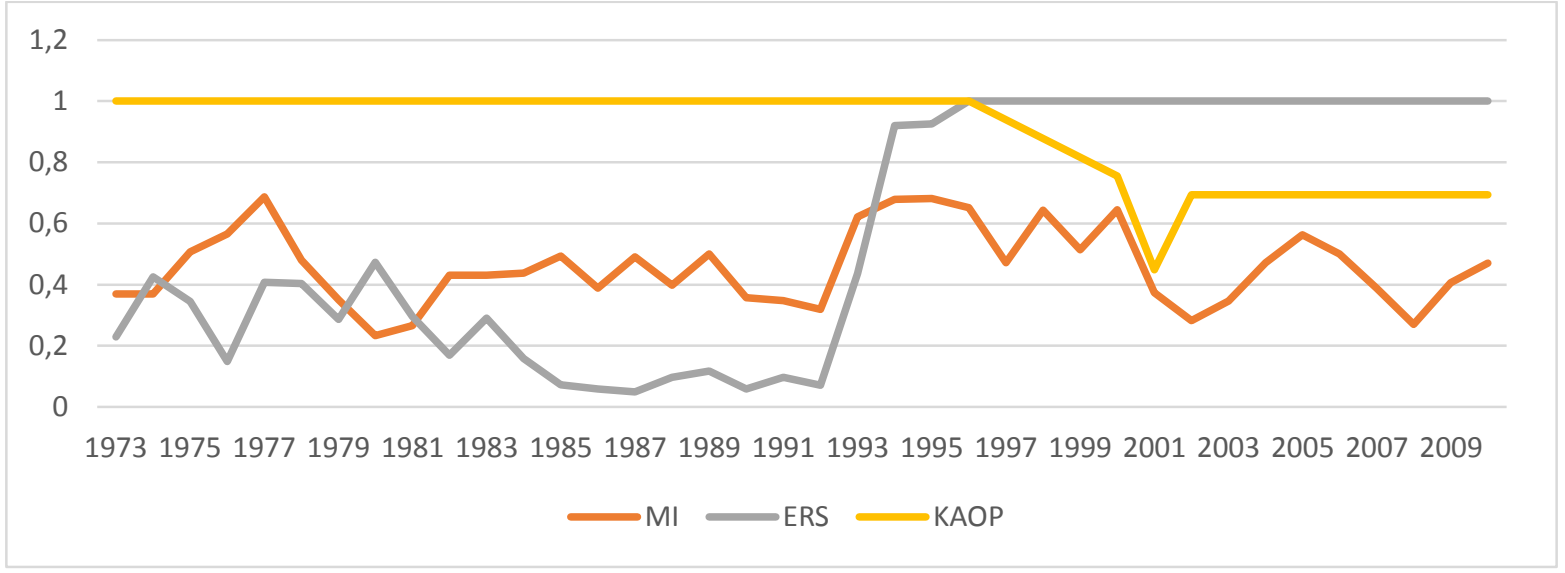


Figure 3a- The evolution of the Monetary Independence Index over years for the Panel

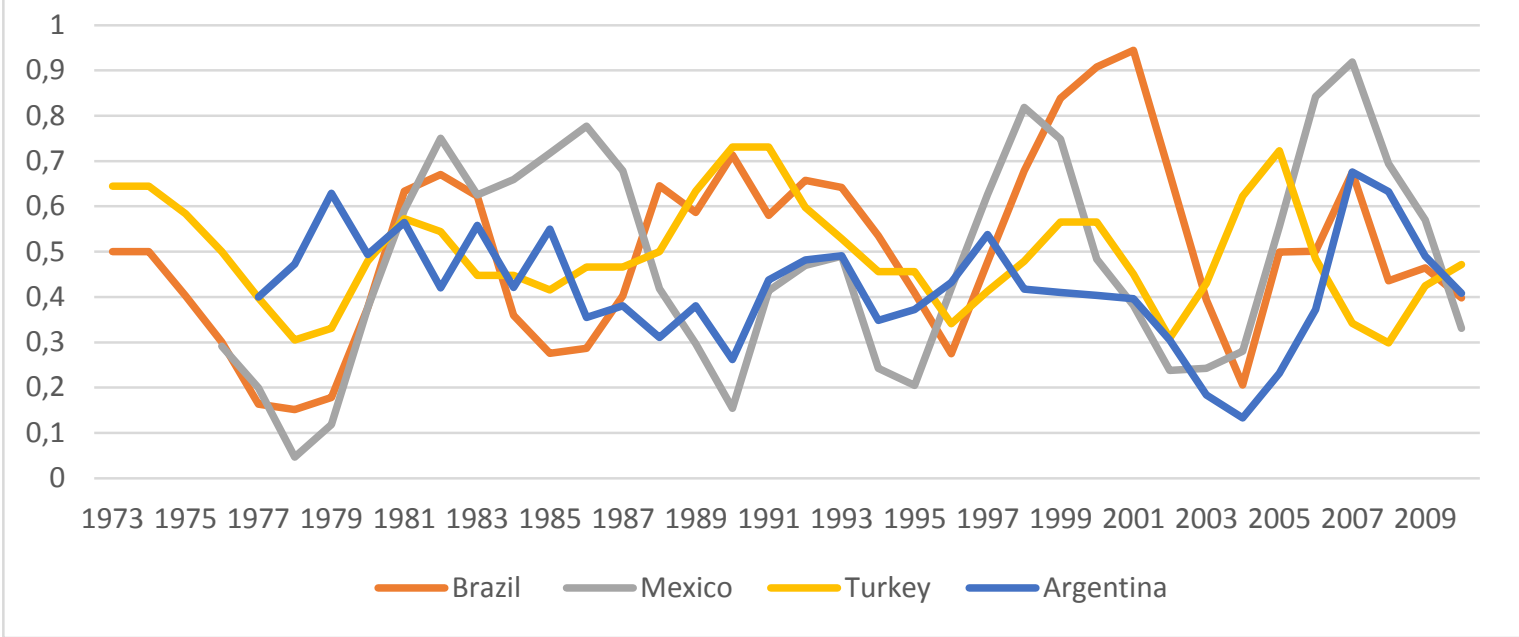

Figure 3b- The evolution of Capital Openness Index over years for the aPanel

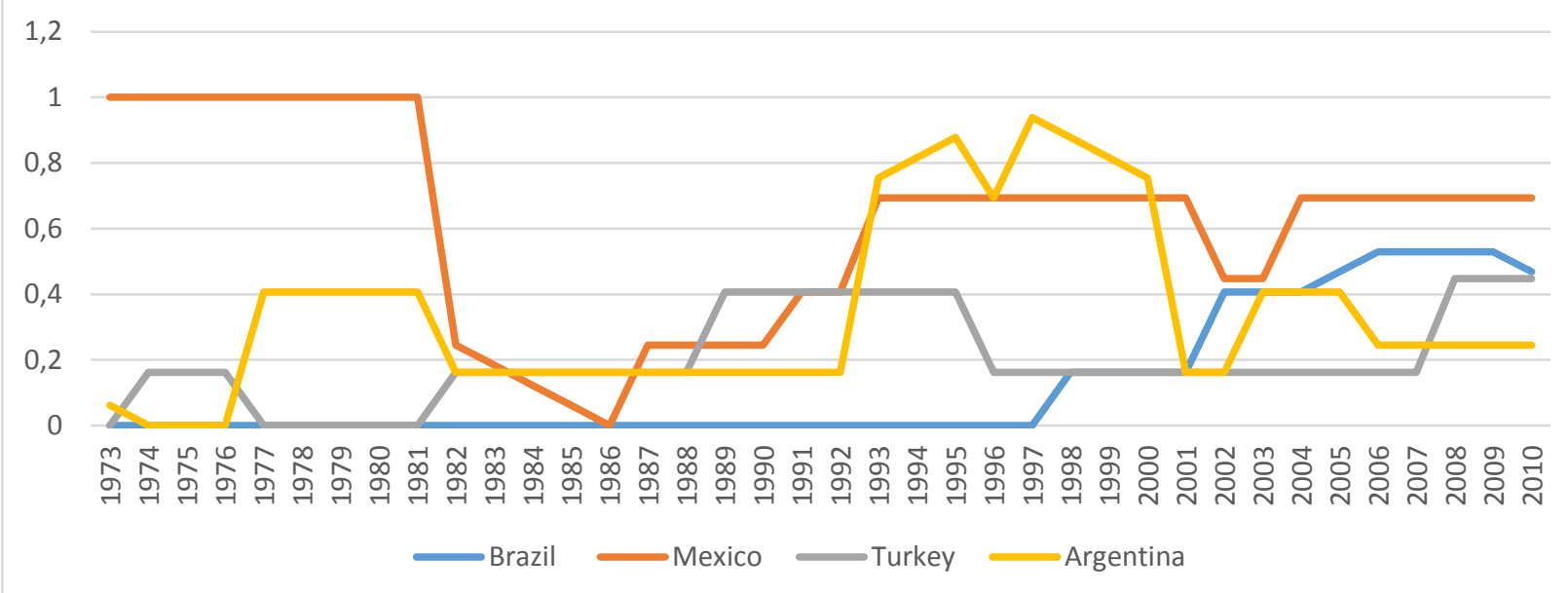

Figure 3c- The evolution of Exchange Rate Stability Index over years for the Panel 1,2

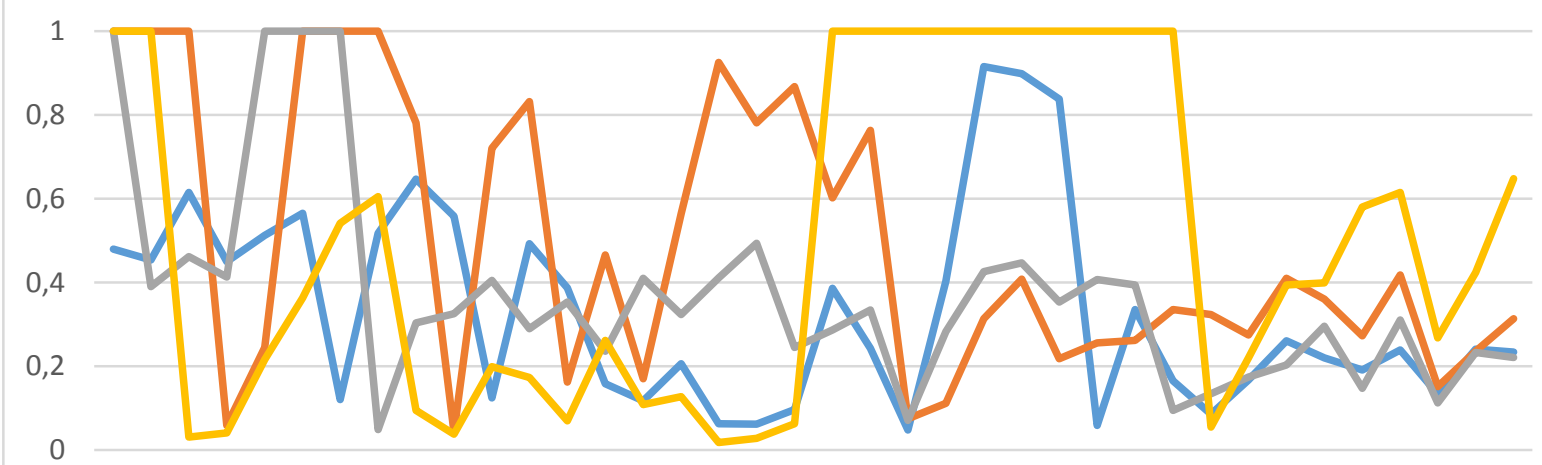

1973197519771979198119831985198719891991199319951997199920012003200520072009 Brazil Mexico Turkey Argentina 
Figure 4a- The Level of International Reserves Lebanon

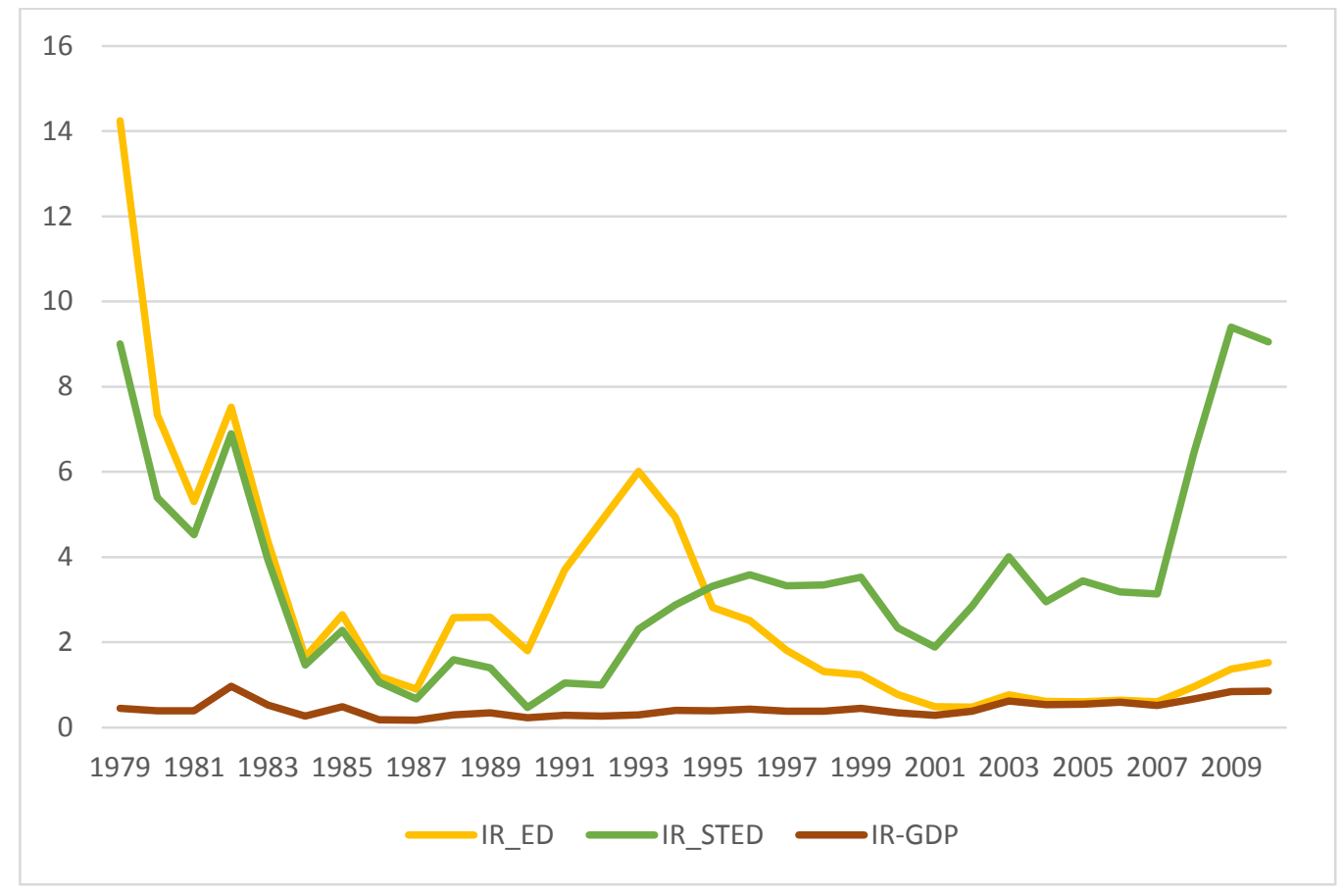

Figure 4b- The Level of International Reserves in Argentina, Brazil, Mexico and Turkey

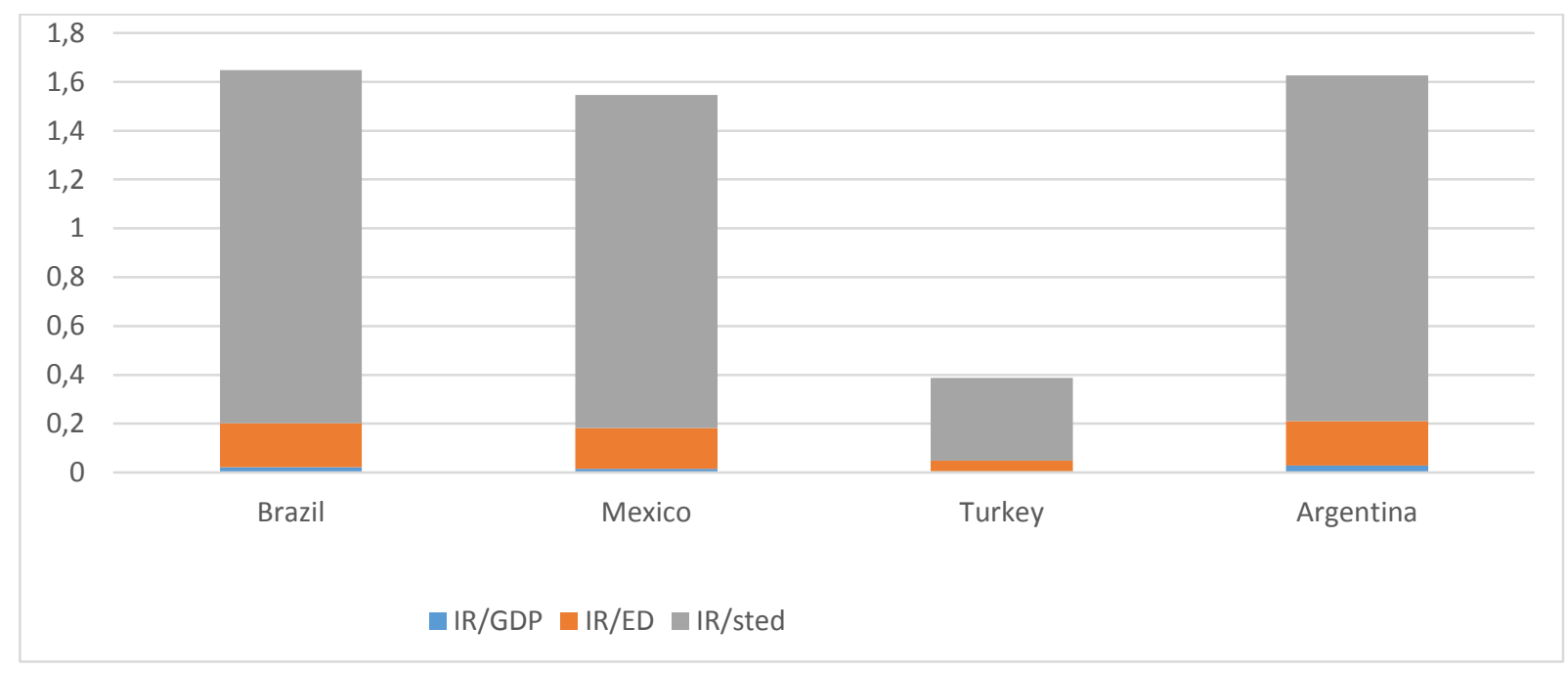


Table 1- Calculation of the Trilemma Indexes of Lebanon from 1973-2010.

Mean

\begin{tabular}{|l|l|l|l|}
\hline & $\mathbf{1 9 7 3 - 2 0 1 0}$ & $\mathbf{1 9 7 3 - 1 9 9 3}$ & $\mathbf{1 9 9 4 - 2 0 1 0}$ \\
\hline ERS & 0.56685 & 0.22359 & 0.9908 \\
\hline MI & 0.458048 & 0.430683 & 0.4918 \\
\hline KAOPEN & 0.896764 & 1 & 0.7692 \\
\hline
\end{tabular}

\section{Coefficient}

\begin{tabular}{|l|l|l|l|}
\hline ERS & $0.655188^{* * *}$ & $-0.0631^{* * *}$ & $1.8495^{* * *}$ \\
\hline MI & -0.31831 & 0.0214 & 0.0525 \\
\hline KO & $1.9176^{* * *}$ & $1.9555^{* * * *}$ & $0.1513^{*}$ \\
\hline Observations & 38 & 21 & 17 \\
\hline Adjusted R Squared & 0.45 & 0.46 & 0.42 \\
\hline
\end{tabular}

Notes: $* * * \mathrm{p}<0.01 * * \mathrm{p}<.05 * \mathrm{p}<0.1$

\begin{tabular}{|c|c|c|c|c|}
\hline Trilemma & & 1973-2010 & 1973-1993 & 1994-2010 \\
\hline \multirow{3}{*}{ Contributions } & ERS & 0.371393 & -0.01411 & 1.832625 \\
\hline & MI & -0.1458 & 0.009217 & 0.0258 \\
\hline & $\mathrm{KO}$ & 1.7196 & 1.955 & 0.1163 \\
\hline $\begin{array}{l}\text { Sum of } \\
\text { Contributions }\end{array}$ & $\sum$ & 1.94522 & 1.9506 & 1.9748 \\
\hline
\end{tabular}

Table 2: Calculation of the Trilemma Indexes of Turkey, Argentina, Brazil and Mexico from 19732010

\begin{tabular}{|c|c|c|c|c|c|c|}
\hline & & $\mathbf{1 9 7 3 - 2 0 1 0}$ & $\mathbf{1 9 7 3 - 1 9 8 2}$ & $\mathbf{1 9 8 3 - 1 9 9 7}$ & $\mathbf{1 9 9 8 - 2 0 0 1}$ & $\mathbf{2 0 0 2 - 2 0 1 0}$ \\
\hline \multirow{3}{*}{ Means } & ERS & 0.42112 & 0.5479 & 0.4070 & 0.482311 & 0.2765 \\
\cline { 2 - 7 } & MI & 0.4744 & 0.4313 & 0.4768 & 0.593134 & 0.4570 \\
\cline { 2 - 7 } & KO & 0.32396 & 0.3037 & 0.2577 & 0.4172 & 0.4152 \\
\hline \multirow{3}{*}{ coefficients } & ERS & $1.1471^{* * *}$ & $1.07 * * *$ & $0.974 * * *$ & $1.2238^{* * * *}$ & $2.3786 * * *$ \\
\cline { 2 - 7 } & MI & $2.3707 * * *$ & $2.4846^{* * *}$ & $2.698^{* * *}$ & $1.8834 * * *$ & $1.34810^{* * *}$ \\
\cline { 2 - 7 } & KO & $0.65505^{* * *}$ & $0.455^{*}$ & $0.416^{*}$ & $0.6589 *$ & 1.4411 \\
\hline Observations & & 113 & 29 & 60 & 12 & 37 \\
\hline $\begin{array}{c}\text { Adjusted R } \\
\text { Squared }\end{array}$ & & 0.36 & 0.65 & 0.63 & 0.62 & 0.15 \\
\hline
\end{tabular}

Notes : Standard errors in parentheses. *** $\mathrm{P}<0,01 ; * * \mathrm{p}<0,05 ; * \mathrm{p}<0,1$

\begin{tabular}{|c|c|c|c|c|c|c|}
\hline & & $\mathbf{1 9 7 3 - 2 0 1 0}$ & $\mathbf{1 9 7 3 - 1 9 8 2}$ & $\mathbf{1 9 8 3 - 1 9 9 7}$ & $\mathbf{1 9 9 8 - 2 0 0 1}$ & $\mathbf{2 0 0 2 - 2 0 1 0}$ \\
\hline \multirow{2}{*}{$\begin{array}{c}\text { Trilemma } \\
\text { Contributions }\end{array}$} & ERS & 0.483071 & 0.586264 & 0.396422 & 0.589867 & 0.63489 \\
\cline { 2 - 7 } & MI & 1.12466 & 1.071837 & 1.286414 & 1.117108 & 0.613737 \\
\cline { 2 - 7 } & KO & 0.212211 & 0.138375 & 0.107319 & 0.274944 & 0.58765 \\
\hline $\begin{array}{c}\text { Sum of } \\
\text { Contributions }\end{array}$ & $\sum$ & 1.819943 & 1.8 & 1.79015 & 1.9819 & 1.83627 \\
\hline
\end{tabular}


Table 3- Calculating the Quadrilemma Indexes of Lebanon from 1977-2010

Table 3a- Means of ERS-MI-KO-IR/GDP, IR/STED and IR/ED

\begin{tabular}{|l|c|c|c|c|}
\hline & & $\mathbf{1 9 7 7 - 2 0 1 0}$ & $\mathbf{1 9 7 7 - 1 9 9 3}$ & $\mathbf{1 9 9 4 - 2 0 1 0}$ \\
\hline \multirow{4}{*}{ Means } & ERS & 0.59973 & 0.208585 & 0.9908 \\
\cline { 2 - 5 } & MI & 0.45866 & 0.425472 & 0.4918 \\
\cline { 2 - 5 } & KO & 0.884618 & 1 & 0.7692 \\
\cline { 2 - 5 } & IR_GDP & 0.452129 & 0.3973 & 0.5068 \\
\cline { 2 - 5 } & IR_STED & 6.9878 & 9.9349 & 4.0407 \\
\cline { 2 - 5 } & IR_ED & 4.8694 & 8.3607 & 1.3781 \\
\hline
\end{tabular}

Table 3b- With IR/GDP

\begin{tabular}{|c|c|c|c|c|}
\hline \multirow{3}{*}{ coefficients } & ERS & $0.586123 * * *$ & $-0.0255^{*}$ & $1.822659 * * *$ \\
\cline { 2 - 5 } & MI & -0.261388 & -0.0066 & 0.089509 \\
\cline { 2 - 5 } & KO & $1.84006^{* * *}$ & $1.9656^{* * *}$ & $0.1373^{*}$ \\
\cline { 2 - 5 } & IR_GDP & $0.2738^{*}$ & $-0.025^{*}$ & 0.02565 \\
\hline Observations & & 34 & 17 & 17 \\
\hline Adjusted R & & 0.5 & 0.31 & 0.55 \\
\hline
\end{tabular}

Notes : Standard errors in parentheses. ${ }^{* * *} \mathrm{P}<0,01 ; * * \mathrm{p}<0,05 ;{ }^{*} \mathrm{p}<0,1$

\begin{tabular}{|c|c|c|c|c|}
\hline & & $\mathbf{1 9 7 7 - 2 0 1 0}$ & $\mathbf{1 9 7 7 - 1 9 9 3}$ & $\mathbf{1 9 9 4 - 2 0 1 0}$ \\
\hline \multirow{3}{*}{ Contributions } & ERS & 0.35151 & -0.005 & 1.8060 \\
\cline { 2 - 5 } & MI & -0.11988 & -0.0028 & 0.044 \\
\cline { 2 - 5 } & KO & 1.62775 & 1.9656 & 0.1056 \\
\cline { 2 - 5 } & IR_GDP & 0.12379 & -0.009993 & 0.0130 \\
\hline $\begin{array}{c}\text { Sum of } \\
\text { Contributions }\end{array}$ & & 1.9831 & 1.9475 & 1.9686 \\
\hline
\end{tabular}


Table $3 c$ - With IR_ED

\begin{tabular}{|c|c|c|c|c|}
\hline \multirow{1}{*}{ coefficients } & ERS & $0.6479 * * *$ & -0.008 & $1.97114 * * *$ \\
\cline { 2 - 5 } & MI & -0.3480 & 0.0110 & 0.0465 \\
\cline { 2 - 5 } & KO & $1.9549 * * *$ & $1.9501 * * *$ & -0.08132 \\
\cline { 2 - 5 } & IR_ED & -0.00357 & $-0.0006 *$ & $0.04 * * *$ \\
\hline Observations & & 34 & 17 & 17 \\
\hline Adjusted R & & 0.68 & 0.37 & 0.31 \\
\hline
\end{tabular}

Notes : Standard errors in parentheses. *** $\mathrm{P}<0,01 ; * * \mathrm{p}<0,05 ;{ }^{*} \mathrm{p}<0,1$

\begin{tabular}{|c|c|c|c|c|}
\hline & & $\mathbf{1 9 7 7 - 2 0 1 0}$ & $\mathbf{1 9 7 7 - 1 9 9 3}$ & $\mathbf{1 9 9 4 - 2 0 1 0}$ \\
\hline \multirow{4}{*}{ Contributions } & ERS & 0.3885 & -0.00172 & 1.9531 \\
\cline { 2 - 5 } & MI & -0.1596 & 0.00468 & 0.02287 \\
\cline { 2 - 5 } & KO & 1.7294 & 1.9501 & -0.0625 \\
\cline { 2 - 5 } & IR_ED & -0.02494 & -0.00501 & 0.0551 \\
\hline $\begin{array}{c}\text { Sum of } \\
\text { Contributions }\end{array}$ & & 1.9333 & 1.9480 & 1.9686 \\
\hline
\end{tabular}

Table 3.d-With IR_STED

\begin{tabular}{|c|c|c|c|c|}
\hline \multirow{3}{*}{ coefficients } & ERS & $0.668^{* * *}$ & -0.0251 & $1.8333 * * *$ \\
\cline { 2 - 5 } & MI & -0.3889 & 0.01132 & 0.0875 \\
\cline { 2 - 5 } & KO & $1.9448^{* * *}$ & $1.949947 * * *$ & $0.13455^{*}$ \\
\cline { 2 - 5 } & IR_STED & -0.0002 & $-0.000205^{*}$ & 0.001378 \\
\hline Observations & & 34 & 17 & 17 \\
\hline Adjusted R & & 0.6 & 0.59 & 0.57 \\
\hline
\end{tabular}

Notes : Standard errors in parentheses. ${ }^{* * *} \mathrm{P}<0,01 ; * * \mathrm{p}<0,05 ; * \mathrm{p}<0,1$

\begin{tabular}{|c|c|c|c|c|}
\hline & & $\mathbf{1 9 7 7 - 2 0 1 0}$ & $\mathbf{1 9 7 7 - 1 9 9 3}$ & $\mathbf{1 9 9 4 - 2 0 1 0}$ \\
\hline Contributions & ERS & 0.40061 & -0.00524 & 1.8165 \\
\cline { 2 - 5 } & MI & -0.1783 & 0.00481 & 0.0430 \\
\cline { 2 - 5 } & KO & 1.7204 & 1.94994 & 0.1035 \\
\cline { 2 - 5 } & IR_STED & -0.00139 & -0.00203 & 0.005568 \\
\hline $\begin{array}{c}\text { Sum of } \\
\text { Contributions }\end{array}$ & & 1.9412 & 1.9474 & 1.9686 \\
\hline
\end{tabular}


Table 4- Calculation of the Quadrilemma Indexes of Turkey, Argentina, Brazil and Mexico from 1973-2010

Table 4a-Means of ERS-MI-KO-IR/GDP, IR/STED and IR/ED

\begin{tabular}{|l|c|c|c|c|c|c|}
\hline & & $\mathbf{1 9 7 3 - 2 0 1 0}$ & $\mathbf{1 9 7 3 - 1 9 8 2}$ & $\mathbf{1 9 8 3 - 1 9 9 7}$ & $\mathbf{1 9 9 8 - 2 0 0 1}$ & $\mathbf{2 0 0 2 - 2 0 1 0}$ \\
\hline \multirow{3}{*}{ Means } & ERS & 0.421124 & 0.54791 & 0.407004 & 0.482311 & 0.276589 \\
\cline { 2 - 7 } & MI & 0.4744 & 0.431392 & 0.476803 & 0.593134 & 0.457049 \\
\cline { 2 - 7 } & KO & 0.323962 & 0.303721 & 0.257793 & 0.417277 & 0.415259 \\
\cline { 2 - 7 } & IR_GDP & 0.057906 & 0.03272 & 0.057906 & 0.069923 & 0.108245 \\
\cline { 2 - 7 } & IR_STED & 1.194586 & 0.808318 & 1.194586 & 1.222992 & 2.402823 \\
\cline { 2 - 7 } & IR_ED & 0.233791 & 0.18975 & 0.233971 & 0.227328 & 0.440466 \\
\hline
\end{tabular}

Table 4b- With IR/GDP

\begin{tabular}{|c|c|c|c|c|c|c|}
\hline \multirow{3}{*}{ coefficients } & ERS & $1.14 * * *$ & $0.939665^{* * *}$ & $0.699067 * * *$ & $0.50877 *$ & $1.3748 * * *$ \\
\cline { 2 - 7 } & MI & $1.8694 * * *$ & $2.10311^{* * *}$ & $2.335116^{* * *}$ & $0.82324 * * *$ & $0.63668^{* *}$ \\
\cline { 2 - 7 } & KO & $0.29967 *$ & $0.467496 * *$ & 0.403433 & $0.54035^{* *}$ & $0.36714 *$ \\
\cline { 2 - 7 } & IR_GDP & $6.5545 * * *$ & $10.76634 * * *$ & $7.26811 * * *$ & $15.6892 * * *$ & $10.888^{* * *}$ \\
\hline Observations & & 113 & 29 & 60 & 12 & 27 \\
\hline Adjusted R & & 0.4 & 0.7 & 0.36 & 0.87 & 0.17 \\
\hline
\end{tabular}

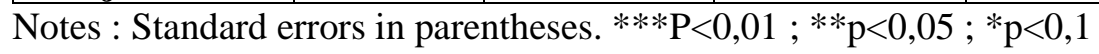

\begin{tabular}{|c|c|c|c|c|c|c|}
\hline & & $\mathbf{1 9 7 3 - 2 0 1 0}$ & $\mathbf{1 9 7 3 - 1 9 8 2}$ & $\mathbf{1 9 8 3 - 1 9 9 7}$ & $\mathbf{1 9 9 8 - 2 0 0 1}$ & $\mathbf{2 0 0 2 - 2 0 1 0}$ \\
\hline \multirow{4}{*}{ Contributions } & ERS & 0.480081 & 0.514852 & 0.284523 & 0.245385 & 0.380255 \\
\cline { 2 - 7 } & MI & 0.886843 & 1.907265 & 1.11339 & 0.488292 & 0.290994 \\
\cline { 2 - 7 } & KO & 0.097082 & 0.141989 & 0.104002 & 0.225476 & 0.152458 \\
\cline { 2 - 6 } & IR_GDP & 0.379584 & 0.352276 & 0.420853 & 1.097029 & 1.178569 \\
\hline $\begin{array}{c}\text { Sum of } \\
\text { Contributions }\end{array}$ & & 1.843554 & 1.916382 & 1.922768 & 2.05 & 2.002 \\
\hline
\end{tabular}


Table 4c - With IR_STED

\begin{tabular}{|c|c|c|c|c|c|c|}
\hline & & $\mathbf{1 9 7 3 - 2 0 1 0}$ & $\mathbf{1 9 7 3 - 1 9 8 2}$ & $\mathbf{1 9 8 3 - 1 9 9 7}$ & $\mathbf{1 9 9 8 - 2 0 0 1}$ & $\mathbf{2 0 0 2 - 2 0 1 0}$ \\
\hline \multirow{3}{*}{ coefficients } & ERS & $1.55825 * * *$ & $0.94152^{* * *}$ & 0.4005 & -0.3607 & $3.392383 * * *$ \\
\cline { 2 - 7 } & MI & $2.0444 * * *$ & $2.0218^{* * *}$ & $2.154256^{* * *}$ & $1.2411^{* * *}$ & $1.5448^{* * *}$ \\
\cline { 2 - 7 } & KO & 0.2167 & $0.57926^{*}$ & $0.74054 * *$ & $-1.94276^{*}$ & -0.7679 \\
\cline { 2 - 7 } & IR_STED & $0.2408^{* * *}$ & 0.4491 & $0.617956^{* * *}$ & $1.39029 * * *$ & $0.24802^{* *}$ \\
\hline Observations & & 132 & 24 & 60 & 16 & 32 \\
\hline Adjusted R & & 0.41 & 0.67 & 0.32 & 0.89 & 0.37 \\
\hline
\end{tabular}

Notes : Standard errors in parentheses. *** $\mathrm{P}<0,01 ; * * \mathrm{p}<0,05 ;{ }^{*} \mathrm{p}<0,1$

\begin{tabular}{|c|c|c|c|c|c|c|}
\hline & & $\mathbf{1 9 7 3 - 2 0 1 0}$ & $\mathbf{1 9 7 3 - 1 9 8 2}$ & $\mathbf{1 9 8 3 - 1 9 9 7}$ & $\mathbf{1 9 9 8 - 2 0 0 1}$ & $\mathbf{2 0 0 2 - 2 0 1 0}$ \\
\hline \multirow{3}{*}{ Contributions } & ERS & 0.656217 & 0.515869 & 0.163005 & -0.17397 & 0.938296 \\
\cline { 2 - 7 } & MI & 0.969863 & 0.872189 & 1.027155 & 0.736138 & 0.706049 \\
\cline { 2 - 7 } & KO & 0.070203 & 0.175934 & 0.190906 & -0.81067 & 0.31888 \\
\cline { 2 - 7 } & IR_STED & 0.287656 & 0.363016 & 0.738202 & 1.700313 & 0.595948 \\
\hline $\begin{array}{c}\text { Sum of } \\
\text { Contributions }\end{array}$ & & 1.983 & 1.927 & 2.11 & 1.451 & 1.921 \\
\hline
\end{tabular}

Table 4d-With IR_ED

\begin{tabular}{|c|c|c|c|c|c|c|}
\hline & & $\mathbf{1 9 7 3 - 2 0 1 0}$ & $\mathbf{1 9 7 3 - 1 9 8 2}$ & $\mathbf{1 9 8 3 - 1 9 9 7}$ & $\mathbf{1 9 9 8 - 2 0 0 1}$ & $\mathbf{2 0 0 2 - 2 0 1 0}$ \\
\hline \multirow{3}{*}{ coefficients } & ERS & $1.10402 * * *$ & $1.018323 * * *$ & $0.524 * * *$ & -0.1129 & $2.982527 * * *$ \\
\cline { 2 - 7 } & MI & $2.08617 *$ & $2.233267 * * *$ & $2.404 * * *$ & $1.05861 * * *$ & $1.447575^{* * *}$ \\
\cline { 2 - 7 } & KO & $0.34494 * * *$ & $0.503244 *$ & 0.490 & -0.3693 & 0.106162 \\
\cline { 2 - 7 } & IR_ED & $1.0627 * * *$ & 0.2807 & $0.172 * * *$ & $5.92293 * * *$ & $0.78664 * * *$ \\
\hline Observations & & 132 & 24 & 60 & 16 & 32 \\
\hline Adjusted R & & 0.4 & 0.62 & 0.31 & 0.69 & 0.32 \\
\hline
\end{tabular}

Notes : Standard errors in parentheses. ${ }^{* * *} \mathrm{P}<0,01 ; * * \mathrm{p}<0,05 ; * \mathrm{p}<0,1$

\begin{tabular}{|c|c|c|c|c|c|c|}
\hline & & $\mathbf{1 9 7 3 - 2 0 1 0}$ & $\mathbf{1 9 7 3 - 1 9 8 2}$ & $\mathbf{1 9 8 3 - 1 9 9 7}$ & $\mathbf{1 9 9 8 - 2 0 0 1}$ & $\mathbf{2 0 0 2 - 2 0 1 0}$ \\
\hline \multirow{3}{*}{ Contributions } & ERS & 0.464929 & 0.55795 & 0.21327 & -0.05445 & 0.824935 \\
\cline { 2 - 7 } & MI & 0.989679 & 0.963414 & 1.146544 & 0.6278 & 0.661613 \\
\cline { 2 - 7 } & KO & 0.111747 & 0.152846 & 0.126546 & -0.1541 & 0.044085 \\
\cline { 2 - 7 } & IR_ED & 0.248641 & 0.155728 & 0.508281 & 1.3464 & 0.346488 \\
\hline $\begin{array}{c}\text { Sum of } \\
\text { Contributions }\end{array}$ & & 1.814 & 1.829 & 1.99 & 1.765 & 1.877 \\
\hline
\end{tabular}


Table 5- The Ourtput Volatility Regression

Table 5a- The Regression with IR/GDP

\begin{tabular}{|c|c|c|c|c|c|c|}
\hline & (1) & (2) & (3) & (4) & (5) & (6) \\
\hline $\begin{array}{l}\text { Relative } \\
\text { income }\end{array}$ & $0.212 * * *$ & $0.201 * * *$ & $0.186^{* * *}$ & $0.166 * * *$ & $0.171 * * *$ & $0.162 * * *$ \\
\hline $\begin{array}{c}\text { Trade } \\
\text { Openness vol }\end{array}$ & $0.141 * * *$ & $0.138 * * *$ & $0.128 * * *$ & $0.120 * * *$ & $0.125 * * *$ & $0.122 * * *$ \\
\hline $\begin{array}{c}\text { Inflation } \\
\text { Rate }\end{array}$ & $\begin{array}{c}0.0000041 \\
0 * *\end{array}$ & $\begin{array}{c}0.00000543 \\
* *\end{array}$ & 0.0000003 & $0.000004 *$ & $\begin{array}{c}0.0000037 \\
2 *\end{array}$ & $\begin{array}{c}0.0000037 \\
8 *\end{array}$ \\
\hline $\begin{array}{l}\text { M2 growth } \\
\text { vol }\end{array}$ & $\begin{array}{c}- \\
0.0000204 \\
* * *\end{array}$ & $\begin{array}{c}0.00000398 \\
* * *\end{array}$ & -0.0000007 & $\begin{array}{c}- \\
0.0000036\end{array}$ & $\begin{array}{c}- \\
0.0000073 \\
4\end{array}$ & $\begin{array}{c}0.0000017 \\
4\end{array}$ \\
\hline $\begin{array}{c}\begin{array}{c}\text { Relative oil } \\
\text { price }\end{array} \\
\end{array}$ & -0.0000506 & -0.0000208 & 0.0000522 & 0.0000389 & 0.0000353 & 0.0000338 \\
\hline $\begin{array}{c}\text { Total } \\
\text { reserve/GDP }\end{array}$ & -0.011 & 0.055 & 0.002 & $0.167 * * *$ & 0.088 & $0.174 * * *$ \\
\hline $\begin{array}{c}\text { US interest } \\
\text { rate }\end{array}$ & $-0.004601 *$ & -0.0036 & 0.001981 & 0.000765 & -0.0083 & -0.000835 \\
\hline $\begin{array}{c}\text { World } \\
\text { Output Gap }\end{array}$ & $\cos _{* *}^{-}$ & $-0.032 * * *$ & $-0.029 * * *$ & $-0.030 * * *$ & $-0.033 * * *$ & $-0.033 * * *$ \\
\hline Inflation Vol & $\begin{array}{c}0.0000177 \\
* * *\end{array}$ & $\begin{array}{c}0.0000134 * \\
* *\end{array}$ & $\begin{array}{c}0.0000165 \\
* * *\end{array}$ & $\begin{array}{c}0.0000120 \\
* *\end{array}$ & $\begin{array}{c}0.0000127 \\
* * *\end{array}$ & $\begin{array}{c}0.0000123 \\
* * *\end{array}$ \\
\hline DCTPS & -0.0002 & 0.00251 & -0.00013 & -0.000162 & -0.00194 & -0.00183 \\
\hline MI & $0.015 * * *$ & 0.0088 & & & 0.010 & $0.017 * * *$ \\
\hline ERS & $-0.024^{*}$ & -0.0011 & $-0.021 * *$ & 0.002258 & & \\
\hline КАОР & & & $-0.020 * * *$ & $-0.16 * *$ & $-0.20 * * *$ & $-0.013 *$ \\
\hline MI*Reserve & & 0.141 & & & 0.108 & \\
\hline $\begin{array}{c}\text { KAOP*Reser } \\
\text { ves }\end{array}$ & & & & -0.094 & & -0.123 \\
\hline $\begin{array}{c}\text { ERS*Reserve } \\
\text { s }\end{array}$ & $0.434 * *$ & & $0.439 * * *$ & & & \\
\hline observations & 124 & 124 & 124 & 124 & 124 & 124 \\
\hline Adjusted R2 & 0.69 & 0.67 & 0.70 & 0.69 & 0.70 & 0.70 \\
\hline
\end{tabular}

Notes: robust standard error $* * * p<0.01 * * p<.05 * \mathrm{p}<0.1$ 
Table 5b-The Regression with IR/ED

\begin{tabular}{|c|c|c|c|c|c|c|}
\hline & (7) & (8) & (9) & (10) & (11) & (12) \\
\hline $\begin{array}{c}\text { Relative } \\
\text { income }\end{array}$ & $0.197 * * *$ & $0.194 * * *$ & $0.174 * * *$ & $0.161 * * *$ & $0.17 * * *$ & $0.1556^{* * *}$ \\
\hline $\begin{array}{c}\text { Trade } \\
\text { Openness vol }\end{array}$ & $0.167 * * *$ & $0.167 * * *$ & $0.152 * * *$ & $0.142 * * *$ & $0.154 * * *$ & $0.143 * * *$ \\
\hline Inflation Rate & $\begin{array}{c}0.00000470 \\
* *\end{array}$ & $\begin{array}{c}0.00000468 \\
* *\end{array}$ & $\begin{array}{c}0.0000042 \\
6^{*}\end{array}$ & $\begin{array}{c}0.000004 \\
60 \\
\end{array}$ & $\begin{array}{c}0.0000028 \\
8 \\
\end{array}$ & $\begin{array}{c}0.0000040 \\
3 \\
\end{array}$ \\
\hline M2 growth vol & 0.00000145 & 0.00000330 & $\begin{array}{c}- \\
0.0000038 \\
3\end{array}$ & $\begin{array}{c}- \\
0.000005 \\
36\end{array}$ & -0.0000882 & -0.0000543 \\
\hline $\begin{array}{c}\text { Relative oil } \\
\text { price }\end{array}$ & $\begin{array}{c}- \\
0.00000938\end{array}$ & 0.0000106 & 0.0000399 & $\begin{array}{c}0.000038 \\
3 \\
\end{array}$ & 0.0000634 & 0.0000298 \\
\hline $\begin{array}{c}\text { Total } \\
\text { reserve/ED }\end{array}$ & -0.005 & 0.013 & 0.0018 & $0.0397 * *$ & 0.0210 & $0.0461 * *$ \\
\hline $\begin{array}{l}\text { US interest } \\
\text { rate }\end{array}$ & -0.0039 & -0.003316 & $\begin{array}{c}- \\
0.001344 * \\
*\end{array}$ & -0.00152 & -0.00566 & -0.001678 \\
\hline $\begin{array}{l}\text { World Output } \\
\text { Gap }\end{array}$ & $-0.032 * * *$ & $-0.032 * * *$ & $\begin{array}{c}- \\
0.030487 * \\
* *\end{array}$ & $\begin{array}{c}- \\
0.03124 * \\
* *\end{array}$ & $\begin{array}{c}- \\
0.033121 * \\
* *\end{array}$ & $-0.0342 * * *$ \\
\hline Inflation Vol & $\begin{array}{c}0.0000130 * \\
* *\end{array}$ & $\begin{array}{c}0.0000131 * \\
* *\end{array}$ & 0.0000111 & $\begin{array}{c}0.000010 \\
4 *\end{array}$ & $\begin{array}{c}0.0000120 \\
* *\end{array}$ & $\begin{array}{c}0.0000108 \\
* *\end{array}$ \\
\hline DCTPS & $\begin{array}{c}- \\
0.000215^{* *}\end{array}$ & $\begin{array}{c}- \\
0.000233 * *\end{array}$ & -0.000151 & -0.000147 & $-0.00192 *$ & -0.000164 \\
\hline MI & $0.017 * * *$ & $0.023 * * *$ & & & $0.0222 * *$ & $0.0199 * * *$ \\
\hline ERS & -0.005 & 0.00739 & -0.0023 & 0.00315 & & \\
\hline KAOP & & & $-0.0224 * * *$ & $-0.0112 *$ & $-0.0207 * * *$ & -0.0065 \\
\hline MI*Reserve & & -0.019 & & & -0.02001 & \\
\hline $\begin{array}{c}\text { KAOP*Reser } \\
\text { ves }\end{array}$ & & & & $-0.268^{*}$ & & $-0.0801 * *$ \\
\hline ERS*Reserves & 0.034 & & 0.0383 & & & \\
\hline observations & 124 & 124 & 124 & 124 & 124 & 124 \\
\hline Adjusted R ${ }^{2}$ & 0.66 & 0.66 & 0.68 & 0.68 & 0.69 & 0.70 \\
\hline
\end{tabular}

Notes: robust standard error $* * * \mathrm{p}<0.01 * * \mathrm{p}<.05 * \mathrm{p}<0.1$ 
Table 5c- Regression with IR/STED

\begin{tabular}{|c|c|c|c|c|c|c|}
\hline & (13) & (14) & (15) & (16) & (17) & (18) \\
\hline $\begin{array}{l}\text { Relative } \\
\text { income }\end{array}$ & $0.195 * * *$ & $0.1947 * * *$ & $0.176^{* * *}$ & $0.162 * * *$ & $0.169 * * *$ & $0.157 * * *$ \\
\hline $\begin{array}{c}\text { Trade } \\
\text { Openness vol }\end{array}$ & $0.160 * * *$ & $0.167 * * *$ & $0.149 * * *$ & $0.145 * * *$ & $0.155 * * *$ & $0.147 * * *$ \\
\hline Inflation Rate & $\begin{array}{c}0.00000536 \\
* *\end{array}$ & $\begin{array}{c}0.00000467 \\
* *\end{array}$ & $\begin{array}{c}0.0000045 \\
8\end{array}$ & 0.00000452 & $\begin{array}{c}0.0000025 \\
9\end{array}$ & 0.0000041 \\
\hline $\begin{array}{l}\text { M2 growth } \\
\text { vol }\end{array}$ & $\begin{array}{c}- \\
0.00000323\end{array}$ & 0.00000375 & $\begin{array}{c}- \\
0.0000037 \\
4\end{array}$ & $\begin{array}{c}- \\
0.00000571\end{array}$ & $\begin{array}{c}0.0000034 \\
8\end{array}$ & -0.0000053 \\
\hline $\begin{array}{c}\text { Relative oil } \\
\text { price }\end{array}$ & -0.000023 & 0.0000161 & 0.000035 & 0.0000414 & 0.0000799 & 0.0000332 \\
\hline $\begin{array}{c}\text { Total } \\
\text { reserve/STED }\end{array}$ & $-0.00437 * *$ & 0.004019 & -0.002328 & $0.0114 * * *$ & 0.00582 & $0.01208 * * *$ \\
\hline $\begin{array}{l}\text { US interest } \\
\text { rate }\end{array}$ & $-0.004648 *$ & -0.002784 & -0.001869 & -0.0000199 & 0.00425 & -0.0000566 \\
\hline $\begin{array}{c}\text { World } \\
\text { Output Gap }\end{array}$ & $-0.0291 * * *$ & $-0.0318 * * *$ & $\begin{array}{c}- \\
0.028398 * \\
* *\end{array}$ & $\begin{array}{c}- \\
0.03135 * * *\end{array}$ & $\begin{array}{c}- \\
0.032374 * \\
* *\end{array}$ & $\begin{array}{c}0.034397 * * \\
*\end{array}$ \\
\hline Inflation Vol & 0.0000099 & $\begin{array}{c}0.00001 .29 \\
* *\end{array}$ & $\begin{array}{c}0.0000088 \\
2 *\end{array}$ & $\begin{array}{c}0.0000129 * \\
* *\end{array}$ & $\begin{array}{c}0.0000120 \\
* *\end{array}$ & $\begin{array}{c}0.0000136^{*} \\
* *\end{array}$ \\
\hline DCTPS & $-0.000179 *$ & $\begin{array}{c}- \\
0.000233 * *\end{array}$ & -0.00125 & -0.00119 & $\begin{array}{c}- \\
0.000182 *\end{array}$ & -0.000136 \\
\hline MI & $0.016 * * *$ & $0.0268 * * *$ & & & $0.02838 * *$ & $0.01966^{* * *}$ \\
\hline ERS & -0.01449 & 0.000704 & -0.00841 & 0.002037 & & \\
\hline KAOP & & & $\begin{array}{c}- \\
0.019336^{*} \\
* *\end{array}$ & -0.00203 & $\begin{array}{c}- \\
0.02047 * * \\
*\end{array}$ & -0.00214 \\
\hline MI*Reserve & $0.0165^{*}$ & -0.00633 & & & -0.008162 & \\
\hline $\begin{array}{l}\text { KAOP*Reser } \\
\text { ves }\end{array}$ & & & & $-0.0187 * * *$ & & $\begin{array}{c}- \\
0.02066 * * *\end{array}$ \\
\hline $\begin{array}{c}\text { ERS*Reserve } \\
\text { s }\end{array}$ & $0.0184 * *$ & & $0.01521 * *$ & & & \\
\hline observations & 124 & 124 & 124 & 124 & 124 & 124 \\
\hline Adjusted R ${ }^{2}$ & 0.68 & 0.66 & 0.69 & 0.70 & 0.69 & 0.71 \\
\hline
\end{tabular}

Notes: robust standard error $* * * \mathrm{p}<0.01 * * \mathrm{p}<.05 * \mathrm{p}<0.1$ 
Table 6a- The Regression of Lebanon with IR/GDP

\begin{tabular}{|c|c|c|c|c|c|c|}
\hline & (1) & (2) & (3) & (4) & (5) & $(6)$ \\
\hline Relative income & $1.221 *$ & -0.4125 & $1.0665^{*}$ & -0.2893 & -0.1829 & 0.8868 \\
\hline $\begin{array}{c}\text { Trade Openness } \\
\text { vol }\end{array}$ & $0.156^{* *}$ & 0.08 & 0.0273 & $0.1224^{*}$ & $\begin{array}{c}0.2248 * * \\
*\end{array}$ & $0.1722 * *$ \\
\hline Inflation Rate & 0.000223 & 0.000125 & $\begin{array}{c}0.000095 \\
6\end{array}$ & 0.0000514 & $\begin{array}{c}0.000004 \\
7\end{array}$ & 0.0000087 \\
\hline M2 growth vol & $-0.2232 * * *$ & $-0.1474 * *$ & $\begin{array}{c}- \\
0.1496 * * \\
*\end{array}$ & $-0.1248 * *$ & $-0.1457 * *$ & $-0.1610 * *$ \\
\hline $\begin{array}{c}\text { Relative oil } \\
\text { price }\end{array}$ & -0.0013 & 0.000394 & -0.000109 & 0.0000083 & $\begin{array}{c}- \\
0.001795 \\
*\end{array}$ & $-0.0017 *$ \\
\hline $\begin{array}{c}\text { Total } \\
\text { reserve/GDP } \\
\end{array}$ & $0.253 *$ & $1.0248 * * *$ & 0.1658 & 0.4678 & -0.1894 & -0.7712 \\
\hline US interest rate & -0.0218 & -0.000657 & -0.018023 & -0.01287 & -0.0545 & -0.0527 \\
\hline $\begin{array}{c}\text { World Output } \\
\text { Gap } \\
\end{array}$ & $0.1268 * * *$ & $0.1094 * * *$ & $\begin{array}{c}0.1036^{* *} \\
*\end{array}$ & $\begin{array}{c}0.112032 * * \\
*\end{array}$ & $\begin{array}{c}0.1172 * * \\
*\end{array}$ & $0.1056 * * *$ \\
\hline Inflation Vol & $\begin{array}{c}0.000728 * \\
*\end{array}$ & 0.000130 & $\begin{array}{c}0.000516 \\
*\end{array}$ & -0.00000802 & 0.00291 & 0.000523 \\
\hline MI & 0.1962 & $0.8793 * * *$ & & & -0.386 & $\begin{array}{c}+0.3075 * \\
*\end{array}$ \\
\hline ERS & 0.0152 & $-0.3325 * * *$ & -0.0374 & $-0.2578 * * *$ & & \\
\hline KAOP & & & $\begin{array}{c}0.2640 * * \\
*\end{array}$ & $0.3363 * * *$ & $0.3304 * *$ & $0.2740 * *$ \\
\hline MI*Reserve & & $\begin{array}{c}2.24702 * * \\
*\end{array}$ & & & 0.0502 & \\
\hline $\begin{array}{c}\text { KAOP*Reserve } \\
\text { s } \\
\end{array}$ & & & & -0.50703 & & 0.6326 \\
\hline ERS*Reserves & $-0.7505 * * *$ & & $-0.5833 * *$ & & & \\
\hline observations & 33 & 33 & 33 & 33 & 33 & 33 \\
\hline Adjusted $R^{2}$ & 0.75 & 0.84 & 0.83 & 0.79 & 0.72 & 0.73 \\
\hline
\end{tabular}

Notes: robust standard error $* * * \mathrm{p}<0.01 * * \mathrm{p}<.05 * \mathrm{p}<0.1$ 
Table 6b-The Regression of Lebanon with IR/ED

\begin{tabular}{|c|c|c|c|c|c|c|}
\hline & (7) & (8) & (9) & (10) & (11) & (12) \\
\hline $\begin{array}{l}\text { Relative } \\
\text { income }\end{array}$ & -0.2601 & -0.142 & -0.0111 & -0.2755 & $-0.7621 * *$ & -0.6874 \\
\hline $\begin{array}{c}\text { Trade } \\
\text { Openness vol }\end{array}$ & $0.2555 * * *$ & $0.1096^{*}$ & $0.1180 * *$ & $0.1314 * * *$ & $0.1387 * *$ & $0.1934 * * *$ \\
\hline Inflation Rate & $0.000267 *$ & $\begin{array}{c}0.000272 * * \\
*\end{array}$ & 0.0000899 & 0.00127 & 0.000141 & $\begin{array}{c}0.0000097 \\
9\end{array}$ \\
\hline M2 growth vol & $0.1413 * * *$ & $-0.0784^{*}$ & $\begin{array}{c}- \\
0.10012 * * \\
*\end{array}$ & $\begin{array}{c}- \\
0.1083^{* * *}\end{array}$ & -0.0589 & $-0.0917 * *$ \\
\hline $\begin{array}{c}\text { Relative oil } \\
\text { price }\end{array}$ & 0.00941 & 0.000288 & 0.001 & 0.000884 & $\begin{array}{c}- \\
0.0000763 \\
\end{array}$ & 0.0000992 \\
\hline $\begin{array}{c}\text { Total } \\
\text { reserve/ED }\end{array}$ & $\begin{array}{c}0.02359 * * \\
*\end{array}$ & $0.0742 * * *$ & $0.0144 * * *$ & $0.4579 * * *$ & $0.0578 * * *$ & 0.0236 \\
\hline US interest rate & 0.0421 & $0.0355 * *$ & $0.0366^{*}$ & $0.0287 *$ & 0.0325 & 0.0249 \\
\hline $\begin{array}{l}\text { World Output } \\
\text { Gap }\end{array}$ & $0.0469^{*}$ & -0.0135 & $0.0432 * *$ & $0.0577 * * *$ & -0.0105 & 0.0348 \\
\hline Inflation Vol & 0.000314 & $0.00637 * * *$ & 0.000210 & 0.000130 & $\begin{array}{c}0.000591 * \\
*\end{array}$ & $0.000364 *$ \\
\hline MI & 0.0481 & $0.2441 * *$ & & & -0.1017 & $0.3445 * * *$ \\
\hline ERS & -0.0712 & $-0.1204 * * *$ & $\begin{array}{c}- \\
0.1503 * * *\end{array}$ & $\begin{array}{c}- \\
0.2526 * * *\end{array}$ & & \\
\hline KAOP & & & $0.2057 * * *$ & $0.2469 * * *$ & 0.1257 & $0.2429 * * *$ \\
\hline MI*Reserve & & $-0.1309 * * *$ & & & $-0.0961 * *$ & \\
\hline $\begin{array}{c}\text { KAOP*Reserve } \\
\text { s }\end{array}$ & & & & $\begin{array}{c}- \\
0.45003 * * \\
*\end{array}$ & & -0.0138 \\
\hline ERS*Reserves & -0.0338 & & -0.0159 & & & \\
\hline observations & 33 & 33 & 33 & 33 & 33 & 33 \\
\hline Adjusted $\mathbf{R}^{2}$ & 0.82 & 0.89 & 0.88 & 0.89 & 0.87 & 0.85 \\
\hline
\end{tabular}

Notes : robust standard error $* * * \mathrm{p}<0.01 * * \mathrm{p}<.05 * \mathrm{p}<0$. 
Table 6c- Regression of Lebanon with IR/STED

\begin{tabular}{|c|c|c|c|c|c|c|}
\hline & (13) & (14) & (15) & $(16)$ & (17) & (18) \\
\hline $\begin{array}{l}\text { Relative } \\
\text { income }\end{array}$ & 0.0119 & -0.6496 & 0.010039 & -0.8615 & -1.0779 & 0.0271 \\
\hline $\begin{array}{c}\text { Trade } \\
\text { Openness vol }\end{array}$ & $0.1750 * * *$ & -0.0366 & -0.0099 & 0.098036 & $0.1777 * *$ & $0.1279^{*}$ \\
\hline Inflation Rate & 0.000175 & 0.0000931 & 0.0000184 & 0.000111 & $\begin{array}{c}- \\
0.0000038 \\
8\end{array}$ & -0.00000672 \\
\hline M2 growth vol & $\begin{array}{c}- \\
0.1697 * * *\end{array}$ & $-0.0906 * *$ & $-0.0929 * *$ & $\begin{array}{c}- \\
0.096037 * \\
*\end{array}$ & $\begin{array}{c}- \\
0.100344 *\end{array}$ & $-0.1117 * *$ \\
\hline $\begin{array}{c}\text { Relative oil } \\
\text { price }\end{array}$ & 0.000936 & $0.001453 * *$ & $0.0011^{*}$ & 0.000891 & -0.000443 & -0.000368 \\
\hline $\begin{array}{c}\text { Total } \\
\text { reserve/STED }\end{array}$ & $0.0441 * *$ & $0.1421 * * *$ & $0.0462 * * *$ & $0.1412 * *$ & 0.023001 & -0.0754 \\
\hline $\begin{array}{l}\text { US interest } \\
\text { rate }\end{array}$ & 0.0402 & $0.0523 * *$ & $0.0471 * *$ & 0.0314 & 0.0131 & 0.0121 \\
\hline $\begin{array}{l}\text { World Output } \\
\text { Gap }\end{array}$ & $0.0527 *$ & -0.0109 & 0.0338 & $0.0616^{* *}$ & 0.0484 & 0.0402 \\
\hline Inflation Vol & $\begin{array}{c}0.000802 * \\
*\end{array}$ & $\begin{array}{c}0.000834 * * \\
*\end{array}$ & $\begin{array}{c}0.000657 * \\
*\end{array}$ & 0.000174 & 0.000593 & $0.000735^{* *}$ \\
\hline MI & 0.1572 & $0.8210 * * *$ & & & $+0.3738^{*}$ & $\begin{array}{c}+0.340006^{* *} \\
*\end{array}$ \\
\hline ERS & -0.0587 & $-0.3239 * * *$ & -0.0436 & $\begin{array}{c}- \\
0.2927 * * *\end{array}$ & & \\
\hline KAOP & & & $0.2785^{* * *}$ & $0.3097 * * *$ & $0.2706^{* *}$ & $0.2489 * *$ \\
\hline MI*Reserve & & $-0.2523 * * *$ & & & -0.0106 & \\
\hline $\begin{array}{c}\text { KAOP*Reserv } \\
\text { es }\end{array}$ & & & & $-0.1238^{*}$ & & 0.0928 \\
\hline ERS*Reserves & $-0.0609^{*}$ & & $-0.0765 * *$ & & & \\
\hline observations & 33 & 33 & 33 & 33 & 33 & 33 \\
\hline Adjusted R ${ }^{2}$ & 0.77 & 0.88 & 0.87 & 0.85 & 0.75 & 0.77 \\
\hline
\end{tabular}

Notes : robust standard error $* * * \mathrm{p}<0.01 * * \mathrm{p}<.05 * \mathrm{p}<0.1$ 